\title{
Palaeoclimate evolution across the Cretaceous-Palaeogene boundary in the Nanxiong Basin (SE China) recorded by red strata and its correlation with marine records
}

\author{
Mingming Ma ${ }^{1,2}$, Xiuming Liu ${ }^{1,2,3}$, and Wenyan Wang ${ }^{1,2}$ \\ ${ }^{1}$ Institute of Geography, Fujian Normal University, Fuzhou, 350007, China \\ ${ }^{2}$ Key Laboratory for Subtropical Mountain Ecology (Funded by the Ministry of Science and Technology and Fujian \\ Province), College of Geographical Sciences, Fujian Normal University, Fuzhou, 350007, China \\ ${ }^{3}$ Department of Environment and Geography, Macquarie University, NSW 2109, Sydney, Australia
}

Correspondence: Xiuming Liu (xliu@fjnu.edu.cn)

Received: 17 October 2017 - Discussion started: 1 November 2017

Revised: 25 January 2018 - Accepted: 2 February 2018 - Published: 8 March 2018

\begin{abstract}
The climate during the Cretaceous Period represented one of the "greenhouse states" of Earth's history. Significant transformation of climate patterns and a mass extinction event characterised by the disappearance of dinosaurs occurred across the Cretaceous-Palaeogene boundary. However, most records of this interval are derived from marine sediments. The continuous and well-exposed red strata of the Nanxiong Basin (SE China) provide ideal material to develop continental records. Considerable research into stratigraphic, palaeontological, chronologic, palaeoclimatic, and tectonic aspects has been carried out for the Datang profile, which is a type section of a non-marine CretaceousPalaeogene stratigraphic division in China. For this study, we reviewed previous work and found that (1) the existing chronological framework of the Datang profile is flawed; (2) precise palaeoclimatic reconstruction is lacking because of the limitations of sampling resolution (e.g. carbonate samples) and/or the lack of efficient proxies; and (3) comparisons of climate changes between marine and continental records are lacking. To resolve these problems, detailed field observations and sampling, as well as environmental magnetic and rare earth element (REE) measurements, were carried out. The results show that (1) more accurate ages of the Datang profile range from 72 to $62.8 \mathrm{Ma}$ based on a combination of the most recently published radiometric, palaeontological, and palaeomagnetic ages; (2) there is considerable evidence of palaeosol generation, which indicates that the red strata formed in a long-term hot, oxidising environment that lacked underwater conditions; (3) haematite was the dominant mag-
\end{abstract}

netic mineral in the red strata, and the variation trend of magnetic susceptibility was consistent with the oxygen isotope records from deep-sea sediments, which indicates that the content of haematite was controlled by the global climate; and (4) the palaeoclimate changes from 72 to $62.8 \mathrm{Ma}$ in the Nanxiong Basin were consistent with global patterns and can be divided into three stages: a relatively hot and wet stage during $72-71.5 \mathrm{Ma}$, a cool and arid stage during 71.5-66 Ma, and a relatively hot and wet stage again during 66-62.8 Ma with a notable drying and cooling event at 64.7-63.4 Ma. Moreover, there are several sub-fluctuations during each stage. This work provides basic information for further palaeoclimate reconstructions with a higher resolution and longer timescales for the Cretaceous to Palaeocene in the Nanxiong Basin and may even help to test ocean-land climate interactions in the future.

\section{Introduction}

The Earth existed in a greenhouse state during the Late Cretaceous (Hay, 2011; Friedrich et al., 2012; Wang et al., 2014); palaeoclimate studies show that based on marine records, the seawater surface temperature near the Equator reached up to $36^{\circ} \mathrm{C}$ during the Late Cretaceous (Linnert et al., 2014), and reconstructed $\mathrm{CO}_{2}$ concentrations reach up to $837 \mathrm{ppm}$ across the Cretaceous-Tertiary boundary, as recorded in palaeosol carbonates in NE China (Huang et al., 2013). The correlation between extreme greenhouse climate 
and high $\mathrm{CO}_{2}$ concentration across this boundary may provide insights for global warming in the present (Wang et al., 2013b). The palaeotemperature decreased significantly from the Mesozoic Era to the Cenozoic (Zachos et al., 2001; Hay, 2011), and a mass extinction event occurred across the Cretaceous-Palaeogene boundary (Schulte et al., 2010; Renne et al., 2013); climate changes and biological evolution during this interval have therefore become a research hot spot. However, most studies of climate change across the Cretaceous-Palaeogene boundary have been derived from marine records (Huber et al., 1995; Barrera and Savin, 1999; Cramer et al., 2009; Friedrich et al., 2012; Bodin et al., 2015). Terrestrial palaeoclimate records are few, and published comparisons and correlations between marine and terrestrial palaeoclimate records are even fewer (Wang et al., 2013b).

There are many basins with Cretaceous continental sediments distributed across China (Li et al., 2013), such as the Songliao Basin (NE China; Wu et al., 2009; Bechtel et al., 2012; Chamberlain et al., 2013; Wang et al., 2013a, b; Wan et al., 2013), the Sichuan Basin (SW China; Li, 1988; Huang et al., 2012; Li et al., 2015), and the Nanxiong Basin (SE China; Zhao et al., 1991, 2002, 2009; Buck et al., 2004; Clyde et al., 2010; Li et al., 2010; Wang et al., 2015), which provide ideal records for investigation of Cretaceous climate change. Among these basins, continuous and well-exposed red strata consisting of mudstone and sandstone are preserved in the Nanxiong Basin, and many fossils have been found in these red strata, such as charophytes, palynomorphs, ostracods, dinosaurs, dinosaur eggs, and mammals (Zhang, 1992; Zhang et al., 2006, 2013; Clyde et al., 2010; Li et al., 2010). Many studies have focused on the Datang profile, which is also called the CGY-CGD profile by Chinese and Germany scientists (Zhao et al., 1991; Yang et al., 1993; Zhao and Yan, 2000). Studies of this profile have investigated its stratigraphy, palaeontology, geochronology, and palaeoclimatology (Zhao et al., 1991; Zhang, 1992; Zhang et al., 2006, 2013; Clyde et al., 2010; Tong et al., 2013; Wang et al., 2015) because it spans from the Upper Cretaceous to the lower Palaeocene and is a type section for non-marine CretaceousPalaeogene stratigraphic division in China. However, precise reconstruction of the palaeoclimatic evolution of this section and comparison with marine records are still lacking because of the lack of efficient proxies. Moreover, many CretaceousPalaeogene records are also lacking from low latitudes in this part of the word; therefore, it is of great significance to carry out palaeoclimate change studies here.

Environmental magnetism as a proxy has been widely used in studies of palaeoclimatic changes in Quaternary loess-palaeosol successions (Evans and Heller, 2001; Hao and Guo, 2005; Maher and Possolo, 2013; Maher, 2016), Tertiary red clay successions (Liu et al., 2003; Nie et al., 2008; Zhao et al., 2016), and other older aeolian deposits (Hao et al., 2008; Zhan et al., 2011), as well as in studies of lake sediments (Snowball et al., 1999; Fu et al., 2015; Hu et al.,
2015) and marine sediments (Larrasoaña et al., 2008; Peters et al., 2010). In this paper, we review previous work (mainly in terms of geochronology and palaeoclimatology) and report some defects in the established chronological framework and palaeoclimatic record. Therefore, the aims of this work are to (1) establish a new chronological framework for the Datang profile, (2) reinterpret the environment in which the red strata formed, (3) try to reconstruct the palaeoclimatic changes using magnetic parameters, and (4) compare the terrestrial records with marine records to provide reliable terrestrial records for future investigation of ocean-land climate interactions.

\section{Geological background, materials, and methods}

\subsection{Geological background}

The Nanxiong Basin $\left(25^{\circ} 03^{\prime}-25^{\circ} 16^{\prime} \mathrm{N}, 114^{\circ} 08^{\prime}-114^{\circ} 40^{\prime} \mathrm{E}\right)$ is a rift basin that developed on pre-Jurassic basement and is controlled by the Nanxiong Fault (Shu et al., 2004). Most of this basin is located in northern Guangdong Province, SE China (Fig. 1a). The basin is elongated with its axis oriented north-east-south-west (Fig. 1b), and is distributed in an area between the Zhuguang and Qingzhang granites (Shu et al., 2004). The modern mean annual rainfall and temperature are $\sim 1555 \mathrm{~mm}$ and $\sim 19.9^{\circ}$, respectively (data from the China Meteorological Data Service Center). Continuous successions of red fluvial-lacustrine clastics, with a maximum thickness of more than $7 \mathrm{~km}$, are preserved in the basin. These successions span the Upper Cretaceous, represented by the dinosaur-bearing Nanxiong Group (Changba, Jiangtou, Yuanpu, Dafeng, Zhutian, and Zhenshui formations), and the lower Palaeocene, represented by the mammal-bearing Luofuzhai Group (Shanghu, Nongshan, and Guchengcun formations; Zhang et al., 2013). Components of conglomerate and coarse-grained sandstone in the basin are similar to those of adjacent strata; moreover, pebbles found in the basin are relatively coarse, poorly sorted, and sharp edged, which implies that the sediment source was not far from the basin (Shu et al., 2004) and that erosion was stable though the Late Cretaceous to Early Palaeocene (Yan et al., 2007).

Several profiles in the basin have been investigated since the 20th century (Zhao et al., 1991, 2002; Zhang and S. Li, 2000; Zhang et al., 2006, 2013; Zhang and G. Li, 2015). Of these profiles, the Datang profile (Fig. 1c), with a vertical thickness of $\sim 700 \mathrm{~m}$, was the most thoroughly investigated because of clear stratigraphic succession and abundant fossils. The Datang profile consists of three formations (Fig. 1d, Zhang et al., 2006); from bottom to top these are the Zhutian Formation (105 m), the Zhenshui Formation ( $295.5 \mathrm{~m}$ ), and the Shanghu Formation ( $288.3 \mathrm{~m}$ ), which are described in detail below (Zhang et al., 2006; Wang, 2012; Zhang, 2016).

The Zhutian Formation consists mainly of brownish red, dark purple, muddy siltstone and silty mudstone with fine 

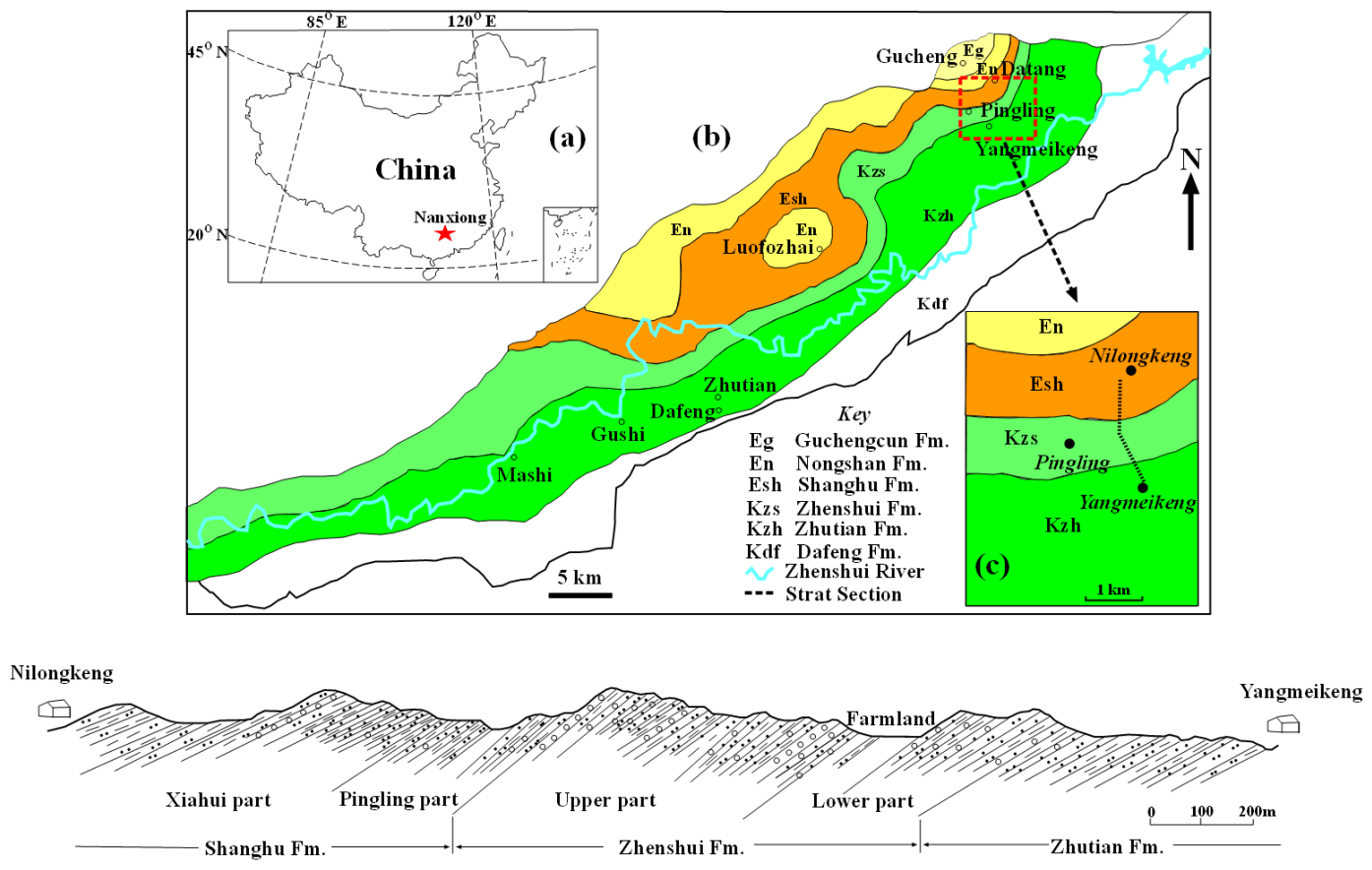

(d)

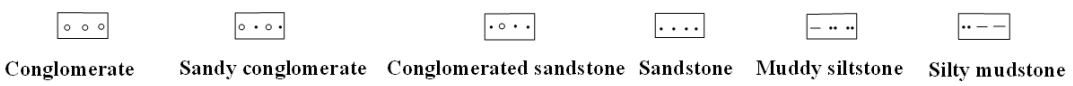

Figure 1. Sketch map of the Nanxiong Basin: (a) location of Nanxiong Basin, (b) stratigraphy of the Nanxiong Basin (from the Dafeng Formation to the Guchengcun Formation; modified from Li et al., 2010), (c) sampling route of the Datang profile, and (d) stratigraphy of the Datang profile (modified from Zhang et al., 2006). Note that the Zhutian Formation in the Datang profile is just the top part of the whole Zhutian Formation.

sandstone interbeds. Large quantities of ostracods and charophytes and minor amounts of gastropods, conchostracans, and dinosaur footprints have been discovered. Several moderately to fully mature palaeosol layers with calcareous nodules generated in this formation.

The Zhenshui Formation is predominantly composed of coarse clastic deposits represented by greyish purple sandstone and conglomerate with red silty mudstone interbeds. This formation is rich in vertebrate and dinosaur eggs, with minor amounts of ostracods, charophytes, bivalves, and gastropods. A few moderately to fully mature palaeosol layers generated in this formation.

The Shanghu Formation is predominantly composed of purple and dark brown muddy siltstone and silty mudstone with numerous calcareous nodules and thin interbeds of sandstone and conglomerate. This formation is rich in microfossils, such as ostracods and charophytes, and also contains fossils of mammals, turtles, gastropods, and pollen. A great deal of moderately to fully mature palaeosol layers generated in this formation.

\subsection{Materials and methods}

Powder samples were collected from the Datang profile; because of strong weathering of the Zhenshui Formation, the sampling intervals for this formation were larger than those for the other formations. To eliminate the effects of particle size on magnetic parameters, the selected samples were mainly muddy siltstone or silty mudstone. All samples were dried naturally in a laboratory, gently ground to disaggregate the grains, and then packed into small non-magnetic plastic boxes $\left(8 \mathrm{~cm}^{3}\right)$ before measurement. Magnetic susceptibility $(\chi)$ was measured using a Bartington MS2B meter at $470 \mathrm{~Hz}$ and then normalised by mass. Anhysteretic remanent magnetisation (ARM) was imparted with a peak AF field of $100 \mathrm{mT}$ and a DC bias field of $0.05 \mathrm{mT}$ using a Molspin alternating field demagnetiser and then measured with a Molspin Minispin magnetometer. Isothermal remanent magnetisation (IRM) was conducted using a Molspin $1 \mathrm{~T}$ pulse magnetiser and measured by employing the Minispin magnetometer. The IRM at $1 \mathrm{~T}$ was regarded as saturation IRM (SIRM). Backfield remagnetisation of SIRM was carried out using reverse fields at $10 \mathrm{mT}$ steps, and remanence coercivity (Bcr) was calculated using linear interpolation. High-temperature mag- 

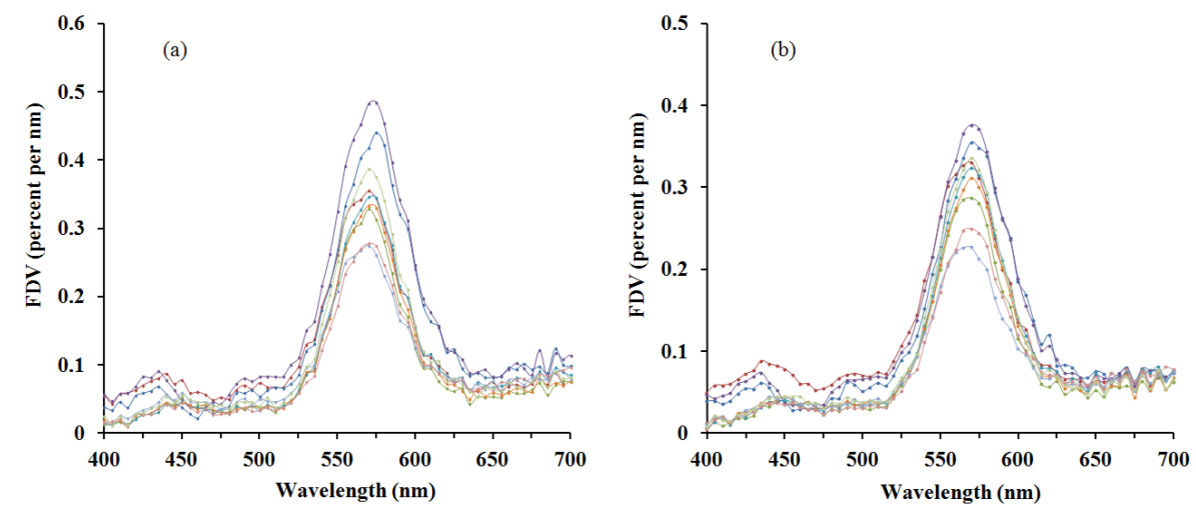

Figure 2. First derivative curves of pilot samples before (a) and after $200^{\circ} \mathrm{C}$ heating (b). After $200^{\circ} \mathrm{C}$ heating, the presence of first derivative peaks are similar to those before heating. All curves show a significant peak at $\sim 575 \mathrm{~nm}$, indicating the existence of haematite.

netic susceptibility curves ( $\kappa-T$ curves) were obtained using an Agico KLY-3 Kappabridge with a CS-3 high-temperature furnace.

Rare earth element (REE) measurements were completed using an X-SERIES inductively coupled plasma mass spectrometer (ICP-MS). Before measurement, bulk samples were successively treated with $\mathrm{HF}$ and $\mathrm{HNO}_{3}(3: 1), \mathrm{HClO}_{4}$, $\mathrm{HNO}_{3}\left(\mathrm{HNO}_{3}: \mathrm{H}_{2} \mathrm{O}=1: 2\right)$, and ultrapure water.

The diffuse reflectance spectroscopy (DRS) of fine powdered samples $(<38 \mu \mathrm{m}$, both before and after heating at $200{ }^{\circ} \mathrm{C}$ for $2 \mathrm{~h}$ ) was recorded from 190 to $1100 \mathrm{~nm}$ in $5 \mathrm{~nm}$ steps using a UV-2600 spectrophotometer (Shimadzu Instruments Manufacturing Co., Ltd.). In this study, only the records from 400 to $700 \mathrm{~nm}$ (visible spectrum) were shown and the first derivative spectral patterns were calculated to determine the presence of haematite and goethite.

All measurements were conducted at the Key Laboratory for Subtropical Mountain Ecology, Fujian Normal University.

\section{Results}

\subsection{DRS}

The DRS technique provides a quantitative method to determine the haematite and goethite, which has been successfully used in marine deposits (Balsam and Deaton, 1991) and loess sections from the Chinese Loess Plateau ( $\mathrm{Ji}$ et al., 2001; Balsam et al., 2004; Torrent et al., 2007). The peaks of the bands at 575 and $435-535 \mathrm{~nm}$ in the first derivative spectral (FDV) patterns are interpreted as haematite and goethite, respectively. However, the clay minerals (such as chlorite and illite) also show peaks at $435 \mathrm{~nm}$ (Ji et al., 2006). In Fig. 2, all curves show a significant peak at $\sim 575 \mathrm{~nm}$, indicating the existence of haematite. There are also small peaks at $\sim 440 \mathrm{~nm}$ which may be related to goethite or clay minerals. However, the $\sim 440 \mathrm{~nm}$ peaks still exist even after $200^{\circ} \mathrm{C}$ heating for $2 \mathrm{~h}$ (Fig. 2b). Goethite will be trans- formed to haematite under $200^{\circ} \mathrm{C}$ (Ma et al., 2013), so the $\sim 440 \mathrm{~nm}$ peaks are probably related to the clay minerals but not goethite.

\section{$3.2 k$ - $T$ curves}

High-temperature $\kappa-T$ curves can be used to identify magnetic phases according to their Curie (Néel) temperatures $\left(T_{\mathrm{c}} / T_{\mathrm{N}}\right)$ or specific decomposition temperatures during the heating process; for example, the $T_{\mathrm{c}} / T_{\mathrm{N}}$ of magnetite and haematite are $\sim 580^{\circ} \mathrm{C}$ (Smith, 1956; Levy et al., 2012) and $\sim 670^{\circ} \mathrm{C}$ (Lu and Meng, 2010), respectively. Partial substitution of $\mathrm{Fe}$ in magnetite or haematite with $\mathrm{Ti}$ or $\mathrm{Al}$ will decrease their $T_{\mathrm{c}}$ temperatures (Jiang et al., 2012, 2015). Maghemite generated during pedogenic processes is generally unstable during heating, as represented by its transformation to haematite at $300-400^{\circ} \mathrm{C}$ (Liu et al., 1999). In addition to being affected by the magnetic mineral type, $\kappa-T$ curves are also affected by magnetic particle size due to the fact that some fine particles can change their domain state during the heating and cooling process (Liu et al., 2005).

The $\kappa-T$ curves of pilot samples from the Datang profile are similar (Fig. 3); heating curves decrease with increasing temperature from room temperature to $\sim 200^{\circ} \mathrm{C}$, which suggests the presence of paramagnetic minerals (Evans and Heller, 2003). They then gradually increases from 200 to $\sim 500-600^{\circ} \mathrm{C}$, which may be related to the unblocking effects of fine magnetic particles (Liu et al., 2005). After this step, a $T_{\mathrm{N}}$ of about $640-660^{\circ} \mathrm{C}$ is shown, which indicates the presence of haematite, and the decreased $T_{\mathrm{N}}$ temperatures may be related to partial substitution of Fe elements with $\mathrm{Al}$ (Jiang et al., 2012, 2015). Most heating and cooling curves are nearly reversible, which indicates that no new magnetic minerals are generated during the heating process; therefore, the haematite is original in the samples. 


\section{3 $\chi$, SIRM, HIRM, and $B_{\mathrm{cr}}$}

The $\chi$ values are controlled by the types, concentrations, and particle sizes of magnetic minerals in the samples; all ferromagnetic, ferrimagnetic, antiferromagnetic, and paramagnetic minerals have effects on $\chi$. In contrast, SIRM, HIRM, and $B_{\mathrm{cr}}$ are not affected by paramagnetic minerals or superparamagnetic particles. Therefore, $\chi$ and SIRM can be used to indicate the concentration of magnetic minerals in cases in which one magnetic mineral is dominant. HIRM can be used to indicate the concentration of hard magnetic minerals such as haematite. The value of $B_{\mathrm{cr}}$ can be used to indicate the ratio of hard to soft magnetic minerals (Thompson and Oldfield, 1986; Evans and Heller, 2003). As shown in Fig. 4, the values of $\chi$, SIRM, and HIRM are low: $\chi$ varies from 1.67 to $19.14 \times 10^{-8} \mathrm{~m}^{3} \mathrm{~kg}^{-1}$ with an average value of $7.25 \times 10^{-8} \mathrm{~m}^{3} \mathrm{~kg}^{-1}$; SIRM varies from 55.27 to $626.26 \times 10^{-5} \mathrm{Am}^{2} \mathrm{~kg}^{-1}$ with an average value of $212.36 \times 10^{-5} \mathrm{Am}^{2} \mathrm{~kg}^{-1}$; and HIRM varies from 24.42 to $341.87 \times 10^{-5} \mathrm{Am}^{2} \mathrm{~kg}^{-1}$ with an average value of $124.11 \times$ $10^{-5} \mathrm{Am}^{2} \mathrm{~kg}^{-1}$. In addition, the variation trends of these three parameters are similar: high with clear fluctuations in the Zhutian Formation, a sharp decrease from the Zhutian Formation to the Zhenshui Formation, low values with numerous fluctuations in the Zhenshui Formation, an increase in the Pingling part of the Shanghu Formation, and an overall decease again with significant variations in the Xiahui part of the Shanghu Formation. The $B_{\mathrm{cr}}$ values vary from 300 to $600 \mathrm{mT}$ with an average value of $430 \mathrm{mT}$, which indicates the dominant role of hard magnetic minerals.

In addition to haematite, there were significant amounts of paramagnetic minerals in the samples, as shown in $\kappa-T$ curves (Fig. 3); the presence of paramagnetic minerals may affect $\chi$ when the overall value of $\chi$ is low. However, SIRM and HIRM are not affected by paramagnetic minerals, and their variation trends are similar to those of $\chi$, which suggests that the variations of $\chi$, SIRM, and HIRM are mainly controlled by the concentration of haematite (Thompson and Oldfield, 1986).

\subsection{REEs}

There are a variety of distribution patterns of REEs in different types of sediments because of their diverse origins and sources and the evolution of the palaeoenvironment. Therefore, REEs can be used as efficient tracer elements (Shunso et al., 2010; Fagel et al., 2014). The $\Sigma$ REE values of the Datang profile samples vary from 153.71 to $210.18 \mu \mathrm{gg}^{-1}$, with an average value of $183.28 \mu \mathrm{gg}^{-1}$. The REE distribution patterns of the pilot samples nearly overlap (Fig. 5); these patterns are characterised by a negative slope, moderate enrichment of LREEs, a relatively flat HREE pattern, and a prominent negative Eu anomaly, which suggests that the provenance of the red strata remained stable (Yan et al., 2007). These patterns are consistent with those of eight samples from the Zhuguang and Qingzhang granites (Shu et al., 2004), which indicates that they are closely related. However, the $\mathrm{Eu}$ anomaly of the granites is more significant than those of the red strata, which is likely related to post-depositional chemical weathering or mixing with other Cambrian-Jurassic sediments (Shu et al., 2004).

\section{Discussion}

\subsection{Chronological framework of the Datang profile}

A great deal of geochronology research, including palaeomagnetic, isotopic, and palaeontological studies, has been carried out on the Datang profile (Zhao et al., 1991; Zhang et al., 2006; Clyde et al., 2010; Li et al., 2010; Tong et al., 2013). The most significant event recorded in this profile is the extinction of the non-avian dinosaurs and the subsequent evolutionary expansion of mammals, which indicates the end of the Cretaceous and the beginning of the Palaeogene (Zhao et al., 1991; Zhang et al., 2006; Clyde et al., 2010). Based on the palaeontological data and two basalt $\mathrm{K}$-Ar ages $(67.04 \pm 2.34,67.37 \pm 1.49 \mathrm{Ma})$ from the top of the Yuanpu Formation (which corresponds to the Zhutian Formation in this paper), Zhao et al. (1991) suggested that the palaeomagnetic age of the Datang profile is between 27R and 31R (Fig. 6a). However, Russell et al. (1993) challenged this chronology because of the wide variation in the sedimentation rate, which varied by more than an order of magnitude during each chron. They proposed an alternative (Fig. 6b) and suggested that several millions of years of deposition was absent from the lowermost part of the Palaeocene record. However, there are some fundamental flaws in the Russell et al. age model. First, a lack of exact ages for palaeomagnetic chron identification made the age model inconclusive. Secondly, based on field observations, no hiatus occurred between the Shanghu Formation and the Zhenshui Formation (Ye, 2000; Zhang et al., 2006). Thirdly, it is reasonable to assume that the sedimentary rate differed during different chrons in the Nanxiong Basin as a continental basin (Ye, 2000). Moreover, two U-Pb ages (59.76 \pm 0.78 , $60.76 \pm 0.90 \mathrm{Ma}$ ) of a tephra layer from the middle part of the Nongshan Formation, above the Shanghu Formation, were recently obtained (Tong et al., 2013) and confirm that the age model of Russell et al. was incorrect. To further clarify the palaeomagnetism framework of the Datang profile, Clyde et al. (2010) collected samples from the uppermost $465 \mathrm{~m}$ of the Datang profile (i.e. the lower part of Zhenshui Formation and Shanghu Formation) and the DT05 profile (Nongshan Formation and the lower part of Guchengcun Formation) and combined the results with palaeontological data and $\delta^{13} \mathrm{C}$ and $\delta^{18} \mathrm{O}$ isotopic composition data from palaeosol carbonates. The results show that the upper $465 \mathrm{~m}$ of the Datang profile has five well-defined polarity zones $(30 \mathrm{~N}, 29 \mathrm{R}, 29 \mathrm{~N}$, $28 \mathrm{R}$, and $28 \mathrm{~N}$ ), whereas the DT05 section is characterised by a single long, reversed-polarity zone (26R), which has been confirmed by the $\mathrm{U}-\mathrm{Pb}$ ages of the tephra layer from the 

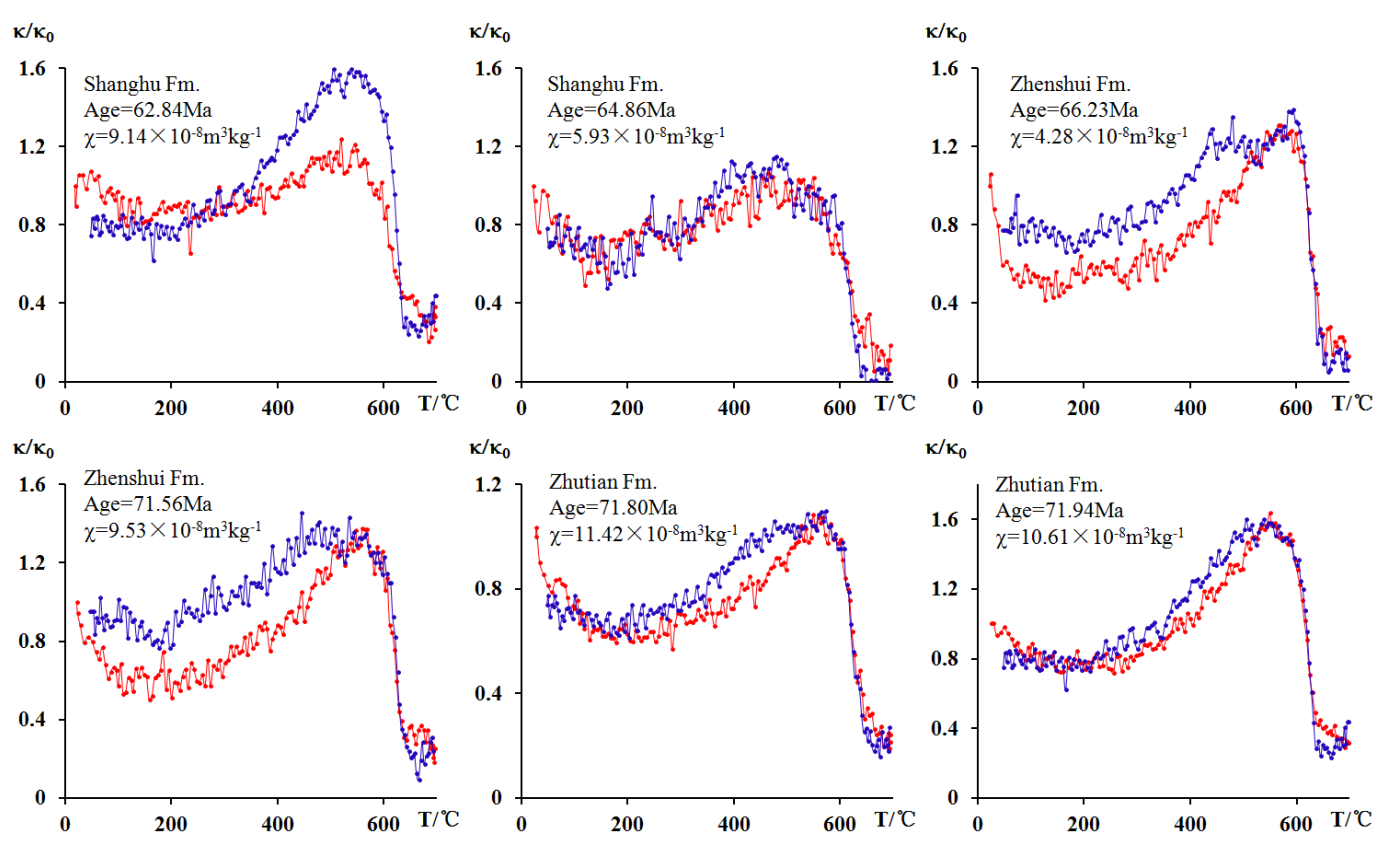

Figure 3. The $\kappa-T$ curves of pilot samples from the Datang profile (red lines represent heating curves, whereas blue lines indicate cooling curves).

Nongshan Formation (Tong et al., 2013) and suggests that this chronological work is reasonable. However, the ages of the Zhutian Formation to the upper part of Zhenshui Formation remain unclear.

The age of the Zhutian Formation to the upper part of the Zhenshui Formation in the Zhao model is controversial; the basalts whose age was used for palaeomagnetic chron identification were actually intrusive rocks that formed after the Zhutian Formation was deposited and therefore cannot be regarded as the top age of the Zhutian Formation. Thus, the top age of the Zhutian Formation should be older than $67.4 \mathrm{Ma}$ (Zhang and $\mathrm{Li}, 2000$ ), and it was confirmed with biostratigraphic data (Tenuestheria) that the Zhenshui Formation correlates with Maastrichtian formations, whereas the Zhutian Formation correlates with lower Santonian-Campanian formations (Li et al., 2010). Therefore, it was incorrect to use 67.4 Ma as the top age of the Zhutian Formation in the Zhao model. The Zhenshui Formation is predominantly composed of coarse clastic deposits, and the top $45.2 \mathrm{~m}$ of the lower part is covered in farmland (Figs. 1d and 6); therefore, it is not possible to obtain samples for palaeomagnetic analysis, which likely led to the absence of two short time chrons 30R (0.173 Myr; Gradstein et al., 2012) and 31N (0.9 Myr; Gradstein et al., 2012) - from the palaeomagnetic results. Therefore, a new alternative can be proposed, as shown in Fig. 6d: 30R, 31N, and 31R in the Zhao model are modified to $31 \mathrm{R}, 32 \mathrm{~N} .1 \mathrm{n}$, and $32 \mathrm{~N}$.1r. The calculated boundary age of the Zhenshui and Zhutian formations is $\sim 71.5 \mathrm{Ma}$ according to the new age model. This is slightly differ from the biostratigraphic age ( $\sim 72.1 \mathrm{Ma}$; i.e. the boundary age be- tween Maastrichtian and Campanian). The reasons are probably (1) the samples for biostratigraphic age, which were collected from the whole Zhutian Formation that is more than $1000 \mathrm{~m}$ in depth, while the Zhutian Formation in the Datang profile is just the top part of the whole Zhutian Formation (Fig. 1), and (2) the dereferences in sampling or time resolution between these two dating methods. Slight error between palaeomagnetic and biostratigraphic ages is therefore reasonable. If $72.1 \mathrm{Ma}$ (within $\mathrm{C} 32 \mathrm{~N} .2 \mathrm{n}$ ) was regarded as the boundary age of the Zhenshui and Zhutian formations, then $30 \mathrm{R}(0.173 \mathrm{Myr}), 31 \mathrm{~N}(0.9 \mathrm{Myr}), 31 \mathrm{R}(2.18 \mathrm{Myr})$, and $32 \mathrm{~N} .1 \mathrm{n}(0.24 \mathrm{Myr})$ were missing due to the covered farmland, and thus only $45.2 \mathrm{~m}$ of sediment was deposited during more than 3.4 Myr, which seems unreasonable to have such a low sedimentary rate in this period. According to the chronological framework obtained above, the bottom and top ages of the Datang profile can be calculated using linear extrapolation as 72 and $62.8 \mathrm{Ma}$, respectively.

\subsection{Sedimentary environment analysis}

Many aquatic fossils, such as ostracods and charophytes, were found in the red strata, and there are many coarse sandstone and conglomerate layers; therefore, the sediments were interpreted as fluvial or lacustrine facies in previous studies (Zhang et al., 2006; Clyde et al., 2010; Wang et al., 2015). In greater detail, the Zhutian Formation was regarded as a floodplain with shallow lake deposits, the Zhenshui Formation was interpreted as fluvial deltaic deposits, and the Shanghu Formation was regarded as shallow lake deposits (Wang, 


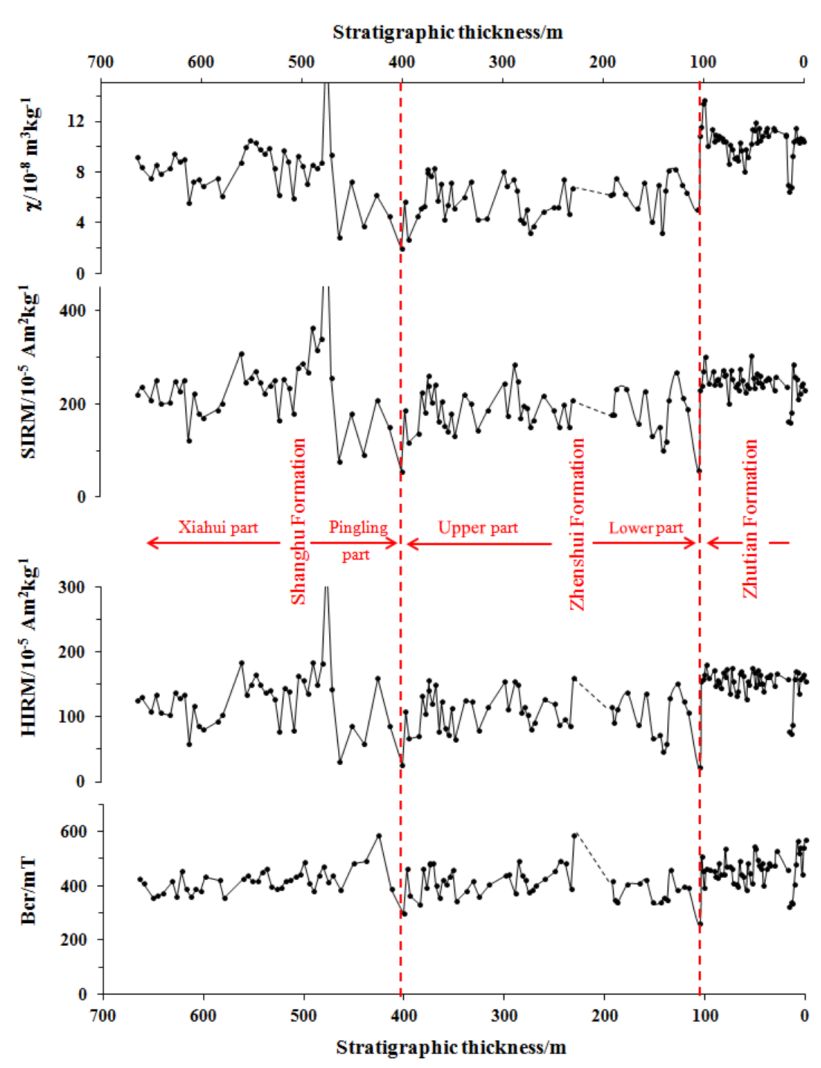

Figure 4. Magnetic parameter variations of the Datang profile; the $x$ axis indicates the stratigraphic thickness from the Zhutian Formation to the Shanghu Formation.

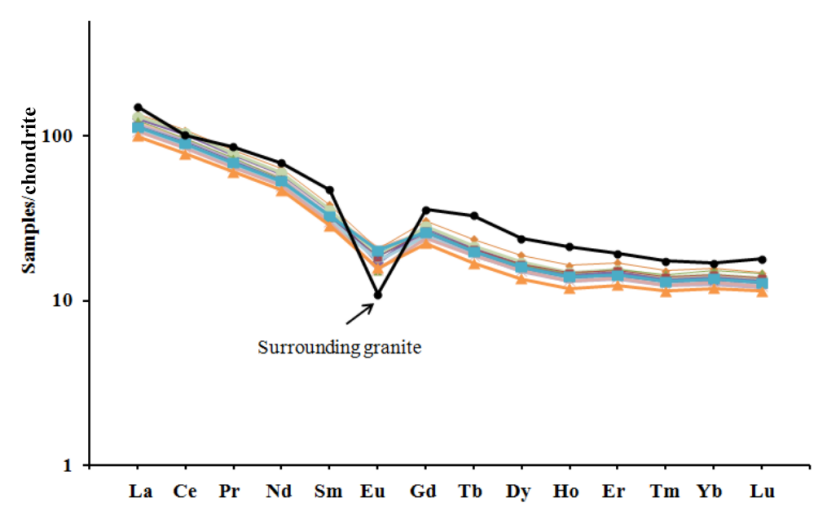

Figure 5. REE distribution patterns (normalised by chondrite) of pilot samples from the Datang profile and samples of the surrounding granite (average values of eight samples; Shu et al., 2004).

2012). However, there are dozens of calcareous nodule layers (Fig. 7a and b),generated by pedogenic processes and distributed in muddy sandstone and sandy mudstone layers (Clyde et al., 2010; Wang, 2012), especially in the Shanghu and Zhutian formations. In addition to calcareous nodules, other evidence for palaeosol formation was found, such as wormhole remains (Fig. 7c and d), root traces (Fig. 7e), and obvious rhizoliths (Fig. 7f). Moreover, many mud cracks are observed in the Datang profile (Fig. 7g and h). Mud cracks mainly form under alternating dry-wet environments, which have traditionally been regarded as an indicator of arid or seasonally arid environments. Environmental magnetic results (Figs. 3 and 4) show that haematite is the dominant magnetic mineral in the red strata. Haematite is an iron oxide that mainly forms and is preserved in oxidising environments and that is dissolved or transformed under excessively wet and reducing conditions. The widely distributed haematite and palaeosols in the Datang profile suggest that the sediments were exposed to a relatively arid and oxidising environment.

The climate during the Cretaceous represented one of the "greenhouse states" of Earth's history; the maximum $\mathrm{CO}_{2}$ concentration was nearly 10 times higher and the temperature $3-10^{\circ}$ higher than those prior to the Industrial Revolution (Huber et al., 2002; Wilson et al., 2002; Retallack, 2009). Although the $\mathrm{CO}_{2}$ concentration decreased in the Late Cretaceous, it was still higher than today (Wang et al., 2014, and the references therein). The Nanxiong Basin was a hot and arid belt according to the palaeoclimate classification of Chumakov et al. (2004). Clumped isotope analysis of pedogenic carbonates has shown that the palaeotemperature could reach up to $27.3-38.2^{\circ}$, with an average value of $34^{\circ}$ (Zhang, 2016), which suggests that the temperature during the Late Cretaceous to Early Palaeocene was much higher than that of the present in this area. In addition, the $\mathrm{CaCO}_{3}$ contents are $10-20 \%$ (wt, Yan et al., 2007) in the red strata, and there are many pedogenic carbonate layers in the sandy mudstone and muddy sandstone, which suggests that the leaching process was weak and that rainfall was moderate (Retallack, 1999, 2005; Yan et al., 2007). TOC concentration is very low (0.027-0.258 wt \%; Yan et al., 2007), which is likely related to the sparse vegetation coverage or oxidising conditions unfavourable for TOC preservation. Therefore, all geochemical parameters indicate that the overall climate during the Late Cretaceous to Early Palaeocene in the Nanxiong Basin was tropical (semi-)arid.

Therefore, the depositional processes of red strata in the Nanxiong Basin under (semi-)arid climate conditions can be inferred as follows. Weathered materials were transported from the surrounding area by run-off caused by rainfall and were then deposited in the basin. During the interval with greater rainfall, temporary rivers or lakes appeared in the basin and provided a habitat for the low-level aquatic organisms, such as ostracods and charophytes, and left abundant fossils of these organisms in the strata. However, the rivers or lakes could not persist for long in a hot, (semi-)arid climate; after the weathered materials were deposited in the basin, these temporary rivers and lakes disappeared because of strong evaporation, and the sediments were then exposed to an oxidising environment. Haematite was thus generated, and the organic matter rapidly decomposed, which led to very low TOC values (Yan et al., 2007). Pedogenic processes then developed, and moderately to fully mature soils with 


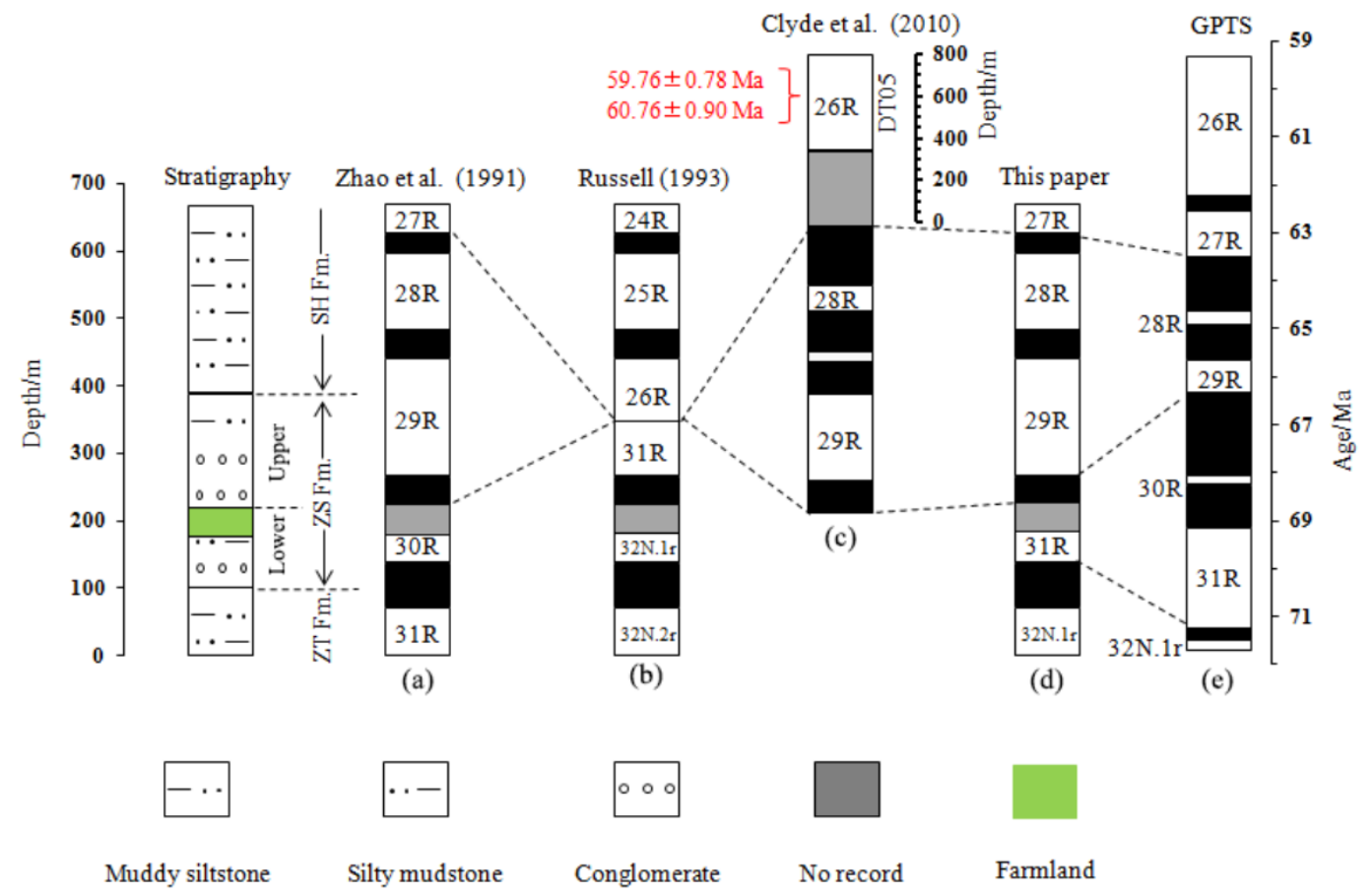

Figure 6. Palaeomagnetic chronology framework of the Datang profile. (a) Zhao et al. (1991); (b) Russell et al. (1993); (c) Clyde et al. (2010); (d) this paper; (e) magnetic polarity timescale (Gradstein et al., 2012).

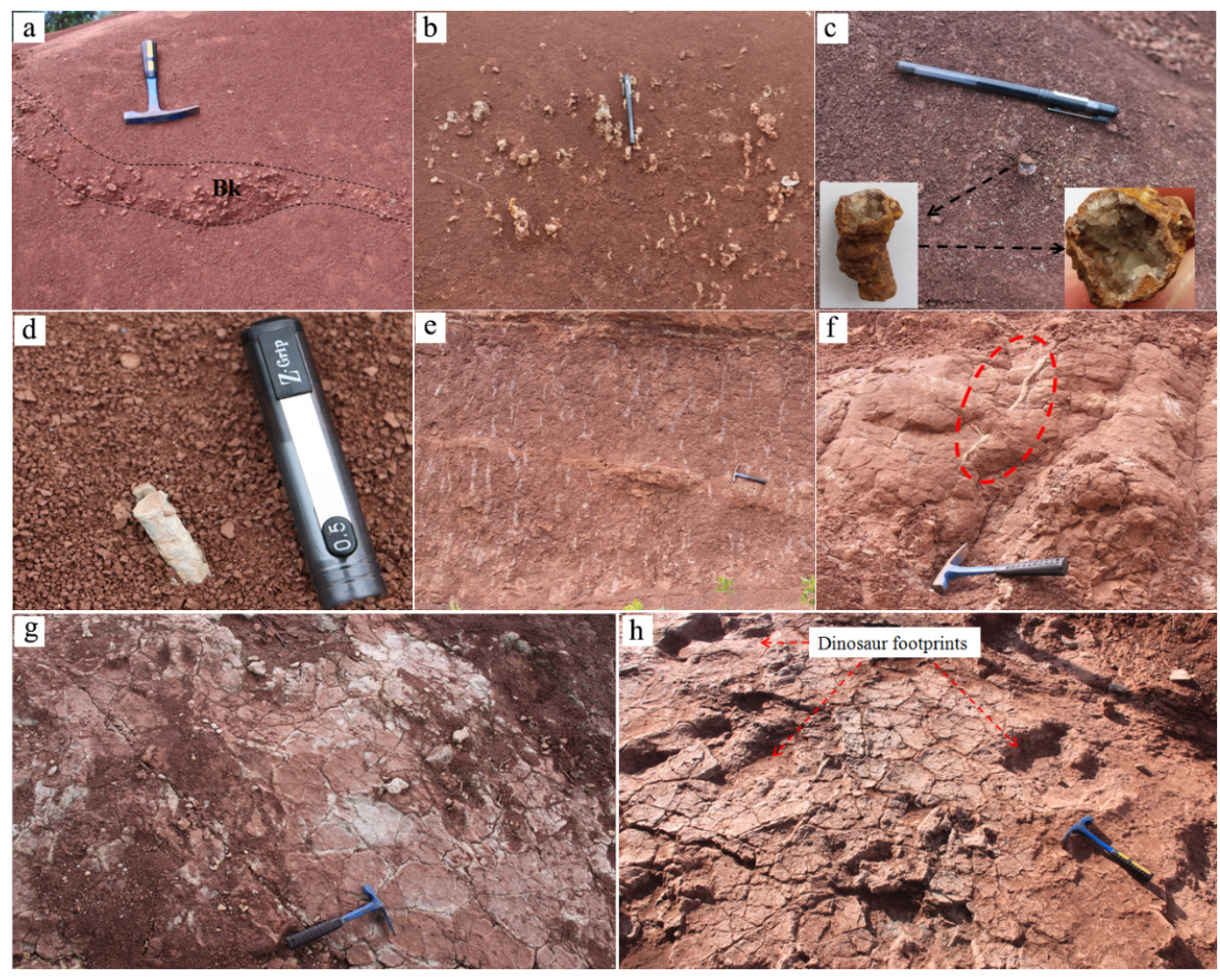

Figure 7. Evidence of palaeosols in the Datang profile: calcareous nodule layers generated during pedogenic processes (a, b), wormhole remains filled with calcite (c) and grey mudstone (d), root traces (e), obvious rhizoliths (f), and mud cracks (g, h). 


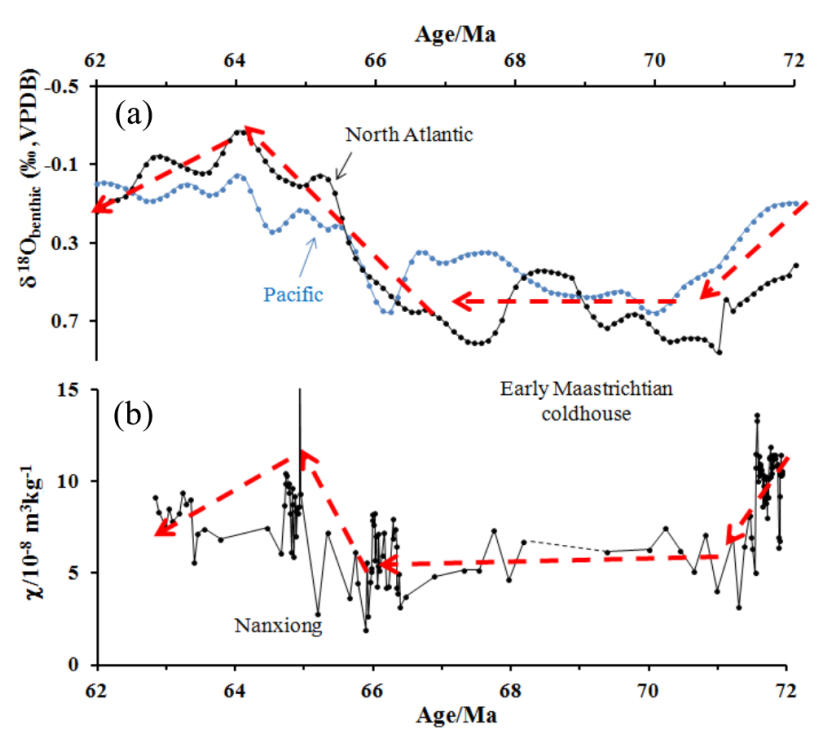

Figure 8. Correlations between $\delta^{18} \mathrm{O}$ from Pacific and North Atlantic records (a) and $\chi$ from the Datang profile (b) from 72 to $62.8 \mathrm{Ma}$; higher $\delta^{18} \mathrm{O}$ values correlate with lower $\chi$ values.

diagnostic characteristics such as Bk horizons, wormholes, and root traces formed in sandy mudstone and muddy sandstone layers. No typical palaeosols were found in the coarse sandstone or conglomerate layers in the Zhenshui Formation because of the lack of essential conditions for soil formation, but many root traces were preserved (Fig. 7e and f), which can be called "weakly developed soils".

\subsection{Comparison between $\chi$ and $\delta^{18} \mathrm{O}$ and the corresponding mechanism}

At present, most high-resolution records of palaeoclimate changes during the Late Cretaceous to Early Palaeogene were derived from marine sediments, with few from continental sediments, which has limited comparison between marine records and continental records and even the study of the dynamic mechanism of palaeoclimate evolution (Wang et al., 2013b). The $\delta^{18} \mathrm{O}$ values of benthic foraminifera in marine sediments faithfully recorded global palaeotemperature changes over the past $200 \mathrm{Myr}$ (Zachos et al., 2001; Friedrich et al., 2012; Bodin et al., 2015), which has provided a high-resolution reference for the study of continental records (Fig. 8a). As shown in Fig. 8, there is a significant negative correlation between $\chi$ and $\delta^{18} \mathrm{O}$ for the Pacific and South Atlantic (Friedrich et al., 2012) from 72 to $62.8 \mathrm{Ma}$ : high (low) $\chi$ values correlate with low (high) $\delta^{18} \mathrm{O}$ values, which suggests that $\chi$ values likely recorded the global palaeoclimate evolution.

The parameter $\chi$ has been widely applied in Chinese Quaternary loess-palaeosol and Tertiary red clay sequences as an efficient palaeoclimatic indicator and correlates well with the $\delta^{18} \mathrm{O}$ values of marine records (Liu, 1985; Nie et al.,
2008). Multiple glacial-interglacial cycles occurred during the Quaternary, and the climate during interglacial periods was warmer and more humid than that of glacial periods, which led to the formation of palaeosols. Palaeosols are magnetically enhanced because of the in situ pedogenic formation of magnetite and maghemite under elevated temperature and rainfall conditions, which led to higher $\chi$ values in palaeosol layers than in loess layers in the Chinese Loess Plateau (CLP; Zhou et al., 1990; Liu et al., 1992; Maher et al., 1994; Chen et al., 2005; Hao and Guo, 2005). The climate was warmer and more humid during the Tertiary than in Quaternary interglacial periods according to red clay records (Ding et al., 1999, 2001), but most $\chi$ values of red clays were lower than those of Quaternary palaeosols and even lower than those of loess layers (Nie et al., 2008), which indicates that the pedogenic hypothesis cannot be simply applied in red clay layers. The dominant magnetic minerals in loess are original magnetite and haematite, with minor amounts of pedogenic maghemite. In contrast, in palaeosol layers, the dominant magnetic minerals are pedogenic maghemite and magnetite, with minor amounts of magnetite, and in red clay layers, the dominant magnetic mineral is pedogenic haematite with minor pedogenic maghemite (Xie, 2008). As mentioned above, the climate when the red clay layers formed was warmer and more humid, and pedogenesis was stronger; consequently, a large amount of ultrafine strongly magnetic minerals such as maghemite and magnetite formed (Nie et al., 2007, 2014, 2016). Previous studies have shown that the low-temperature oxidation (LTO) of magnetite is a common process during weathering (Van Velzen and Dekkers, 1999) that gradually alters magnetite into maghemite (magnemitisation). Moreover, chemical weathering can transform maghemite into haematite (Sidhu, 1988; Torrent et al., 2006; Zhang et al., 2012; Fang et al., 2015; Hu et al., 2015). The magnetic minerals in red clays underwent stronger oxidation than Quaternary loess-palaeosol sequences (Nie et al., 2016), which likely caused most soft magnetic minerals (magnetite and maghemite) to transform into hard magnetic mineral haematite under LTO and chemical weathering processes and led to a significant decrease in $\chi$ values in red clay. Nonetheless, the $\chi$ values of red clay can still be used as an efficient palaeoclimatic indicator (Nie et al., 2008; Zhao et al., 2016).

Generally, palaeosols, even without burial or original gleisation in deep time, have systematically lower $\chi$, such as observed for Precambrian and Palaeozoic palaeosols (Retallack et al., 2003). Two possible explanations for this finding have been proposed: (1) recrystallisation and metamorphism of magnetite and maghemite (Retallack, 1991) and (2) lower biological productivity of such deeply buried and ancient soils (Schwartzmann and Volk, 1991). However, these two possibilities require further testing of palaeosols with a wider range of geological ages and degrees of burial alteration (Retallack et al., 2003). Despite the low values of $\chi$ in many of these deep time palaeosols, many studies have concluded that the magnetic minerals preserved in these soils are pe- 


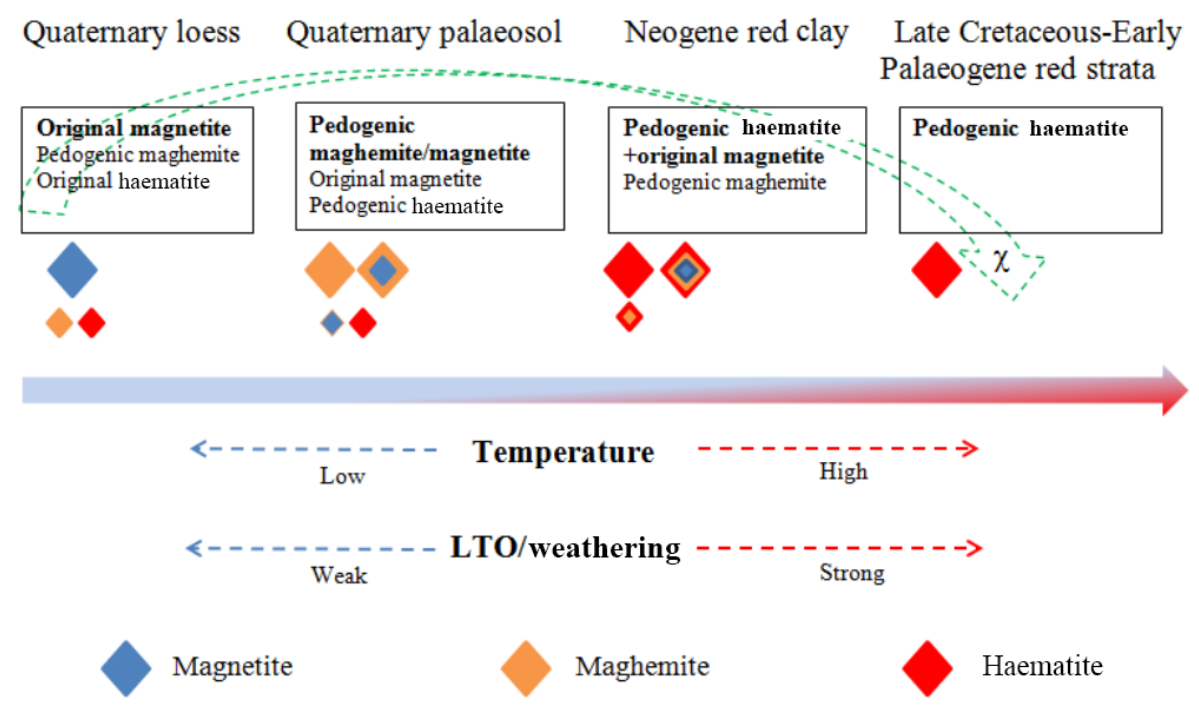

Figure 9. Cartoon illustrating the dominant magnetic minerals and $\chi$ changes from Quaternary loess-palaeosol (CLP) $\rightarrow$ Neogene red clay $($ CLP $) \rightarrow$ Upper Cretaceous-lower Palaeogene red strata in the Nanxiong Basin along with the increased temperature and LTO and/or chemical weathering (the size of the symbols indicates the contribution to $\chi$ but not the real size of magnetic particles).

dogenic (Rankey and Farr, 1997; Cogoini et al., 2001; Tramp et al., 2004). Therefore, we propose another possibility to explain the low $\chi$ in the Nanxiong red strata. The global climate during the Late Cretaceous to Early Palaeocene was much warmer than that of the Neogene and Quaternary (Friedrich et al., 2012; Bodin et al., 2015). The Chemical Index of Alteration (CIA) values of red strata in the Nanxiong Basin (70-80; Yan et al., 2007) are higher than those of Quaternary loess-palaeosol and Tertiary red clay (61-71; Chen et al., 2001; Xiong et al., 2010), which suggests that the red strata underwent stronger chemical weathering. The climate during the Late Cretaceous to Early Palaeocene in the Nanxiong Basin was hot and (semi-)arid with a certain amount of rainfall, as represented by the presence of temporary rivers and shallow lakes (or low-lying land) and palaeosols with calcareous nodules (Retallack, 1999, 2005), which favoured the LTO of magnetite and the transformation of maghemite to haematite through chemical weathering, caused haematite to be the main magnetic mineral in the red strata (Figs. 2 and 3), and significantly decreased $\chi$. This process is summarised in Fig. 9. The global climate was unstable from 72 to $62.8 \mathrm{Ma}$, as represented by multiple cycles of cold-warm changes (Fig. 8a). Higher $\chi$ values occurred in warmer periods (lower $\delta^{18} \mathrm{O}$ values), which is similar to the correlation between the $\chi$ values of Chinese loess-palaeosol-red clay successions and $\delta^{18} \mathrm{O}$ (Liu, 1985; Nie et al., 2008). There may be two reasons for the changes in $\chi$ : (1) changes in sediment provenance and (2) palaeoclimatic evolution. REE distribution patterns show that the sediment provenance remained similar in the Datang profile (Fig. 4) and even across the whole basin (Yan et al., 2007), which indicates that palaeoclimatic evolution was the main reason for changes in $\chi$. There are sig- nificantly positive correlations between $\chi$, SIRM, and HIRM (Fig. 4), which suggests that $\chi$ was controlled by the concentration of haematite (Figs. 3 and 4), whereas haematite was generated through LTO and chemical weathering during pedogenesis. Thus, the relationship between $\chi$ and haematite content can be explained by the "pedogenic-plus hypothesis": more haematite formed during warmer and wetter periods with stronger pedogenesis and caused a higher $\chi$, and opposite conditions yielded lower $\chi$ values. The similarity of the $\chi$ and $\delta^{18} \mathrm{O}$ curves suggests that the climate changes in the Nanxiong Basin during 72-62.8 Ma were similar to global trends; therefore, $\chi$ can still be used as an efficient indicator for palaeoclimate changes in this basin.

Hasegawa et al. (2012) found that the subtropical highpressure belt was located between ca. 31 and $37^{\circ} \mathrm{N}$ during the Late Cretaceous based on spatio-temporal changes in the latitudinal distribution of deserts in the Asian interior, and thus the Nanxiong Basin $\left(\sim 22^{\circ} \mathrm{N}\right.$; Scotese, 2014$)$ was out of the area covered by the subtropical high-pressure belt. Computer simulation results revealed that the prevailing wind directions showed a remarkable seasonal variation over East Asia at $66 \mathrm{Ma}$, which indicates a monsoon feature over East Asia at that time (Chen et al., 2013). Even more remarkable compared to the present day, this was supported by geological evidence (Jiang et al., 2008), and rainfall also showed seasonal variation between dry and wet seasons corresponding to the monsoon (Chen et al., 2013). In addition, the root traces in Zhenshui Formation consisting of elongated grey mottles with red or purple hypocoatings (Fig. 7e) indicate a relatively well-drained soil condition (Kraus and and Hasiotis, 2006), which is favourable for the formation and preservation of haematite. Therefore, the monsoon system already 
existed and the rainfall also showed seasonal variation across the Cretaceous-Palaeogene boundary, but the climate was hotter and drier than present, so a great deal of haematite generated during pedogenic processes under well-drained conditions and thus recorded global climate evolutions.

\subsection{Palaeoclimatic evolution of the Nanxiong Basin during 72-62.8 Ma}

Based on changes in the relative content of clay, the ratio of feldspar to quartz (F/Q), and the $\delta^{18} \mathrm{O}$ of pedogenic carbonates, Wang (2012) and Wang et al. (2015) divided the palaeoclimatic changes recorded in the Datang profile into three stages: an arid to semi-arid climate from the Zhutian Formation to the bottom of the Pingling part of the Shanghu Formation, a semi-arid to hot and humid climate from the bottom of the Pingling part to the bottom of the Xiahui part of the Shanghu Formation, and the semi-arid climate of the Xiahui part. Their age model follows the palaeomagnetic framework of Zhao et al. (1991; Fig. 6a). In contrast, Yan et al. (2007) suggested that a long period of extremely dry climate occurred in the Late Cretaceous and that the climate then became relatively wet in the Early Palaeocene based on $\mathrm{CaCO}_{3}$ and TOC contents as well as the ratios of $\mathrm{Rb} / \mathrm{Ti}$ and $\mathrm{Cs} / \mathrm{Ti}$. Furthermore, quantitative palaeotemperature data have been successfully determined; for example, clumped isotope analysis of pedogenic carbonates revealed that the palaeotemperature reached up to $27.3-38.2^{\circ} \mathrm{C}$ with an average value of $34^{\circ} \mathrm{C}$ (Zhang, 2016). Although a considerable amount of work has been conducted on these palaeoclimatic changes, the reconstructed results cannot be compared efficiently with global records. One reason may be the low resolution of quantitative palaeotemperature data due to the limitations of sampling (e.g. pedogenic carbonates), and another may be that the geochronological framework is incorrect (Sect. 4.1). As shown in previous studies, the $\delta^{18} \mathrm{O}$ of pedogenic carbonates was found to be an efficient palaeotemperature indicator in terrestrial sediments; greater $\delta^{18} \mathrm{O}$ values indicate higher palaeotemperatures (Han et al., 1997; Chamberlain et al., 2012; Gao et al., 2015). In addition, the haematite in the Nanxiong Basin is partially Alsubstituted (Fig. 3); indoor examination revealed that there was a negative correlation between $T_{\mathrm{N}}$ and the $\mathrm{Al}$ content of Al-substituted haematite (Jiang et al., 2012), and greater Al content in haematite likely indicates stronger pedogenesis. Therefore, we combined these results with the $\chi$ curve, $\delta^{18} \mathrm{O}$ of pedogenic carbonates (Fig. 10b, Clyde et al., 2010; Wang, 2012), and $T_{\mathrm{N}}$ of the pilot samples (Fig. 10c) to reconstruct the climatic evolution of the Nanxiong Basin during 72 to $62.8 \mathrm{Ma}$.

Although the palaeoclimate from 72 to $62.8 \mathrm{Ma}$ in the Nanxiong Basin was overall hot and (semi-)arid, it can be divided into three stages, as shown in Fig. 10. For stage I (from 72 to $71.5 \mathrm{Ma}$; Zhutian Formation), $\chi$ and $\delta^{18} \mathrm{O}$ values of pedogenic carbonates are relatively high, and $T_{\mathrm{N}}$ is rela-

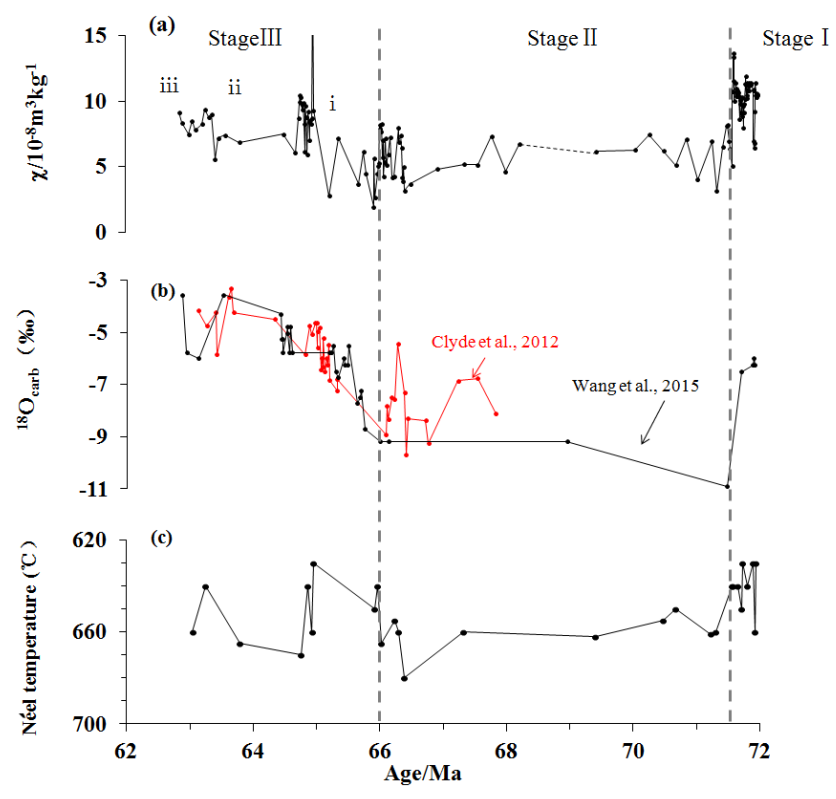

Figure 10. Combined proxies for palaeoclimatic changes in the Nanxiong Basin from 72 to $62.8 \mathrm{Ma}$, (a) $\chi$ curve, (b) $\delta^{18} \mathrm{O}$ of pedogenic carbonates (Clyde et al., 2010; Wang, 2012), and (c) $T_{\mathrm{N}}$ of Al-substituted haematite in pilot samples.

tively low and varies from 630 to $660{ }^{\circ} \mathrm{C}$ with a mean value of $640^{\circ} \mathrm{C}$, whereas the $\delta^{18} \mathrm{O}$ values of marine sediments are relatively low (Fig. 8); the sediments are mainly composed of muddy siltstone and silty mudstone (shallow lake facies), which indicate a relatively hot and wet climate with stronger pedogenic processes and clear fluctuations, such as the rapid drying and cooling event at $\sim 71.7 \mathrm{Ma}$ represented by low $\chi$ values. In stage II (from 71.5 to $66 \mathrm{Ma}$; Zhenshui Formation), $\chi$ decreases sharply at $71.5 \mathrm{Ma}$ and then fluctuates steadily, $\delta^{18} \mathrm{O}$ values of pedogenic carbonates show a similar trend to $\chi, T_{\mathrm{N}}$ is relatively high and varies from 640 to $680^{\circ} \mathrm{C}$ with a mean value of $660^{\circ} \mathrm{C}, \delta^{18} \mathrm{O}$ of marine sediments first increases and then fluctuates at a high level, and the sediments are mainly composed of coarse sandstone and conglomerate (fluvial delta facies), which indicates a relatively cool and arid climate with weak pedogenesis. These findings are supported by sparse pollen data that show the appearance of the Pinaceae and disappearances of tropical plants in the upper Zhenshui Formation, which indicates a cold climate (Erben et al., 1995). In Stage III (from 66 to 62.8 Ma; Shanghu Formation), $\chi$ increases sharply from 66 to $\sim 64.7 \mathrm{Ma}$, then decreases sharply at $64.7 \mathrm{Ma}$, maintains relative low values from 64.7 to $\sim 63.4 \mathrm{Ma}$, and then returns to high values from 63.4 to $62.8 \mathrm{Ma} ; \delta^{18} \mathrm{O}$ values of pedogenic carbonates increase rapidly from 66 to $\sim 64.7 \mathrm{Ma}$ and then maintain high values from 64.7 to $\sim 62.8 \mathrm{Ma} ; T_{\mathrm{N}}$ of pilot samples and $\delta^{18} \mathrm{O}$ of marine sediments show opposite trends from $\chi$; the sediments from $66-62.8 \mathrm{Ma}$ are mainly composed of muddy siltstone and silty mudstone (shallow lake 
facies). In addition, sparse pollen analyses have shown that the climate was temperate-subtropical at the bottom of the Pingling part ( $\sim 66$ to $\sim 65 \mathrm{Ma} ; \mathrm{Li}, 1989)$, whereas it was cool and arid in the Xiahui part (Zhang, 1981). Therefore, the climate changes in this stage can be divided into three sub-stages: in sub-stage i (66-64.7 Ma), the climate quickly became relatively hot and wet from relatively cool and arid conditions; in sub-stage ii (64.7-63.4 Ma), the climate experienced a drying and cooling event represented by low $\chi$ values; in sub-stage iii (63.4-62.8 Ma), the climate became relatively hot and wet again. Although the constructed climate evolution revealed by magnetic parameters is still qualitative, it shows more details than other proxies or the marine record, such as several sub-fluctuations during each stage, which probably indicates that the climate changes from 72 to 62.8 Ma were unstable with more fluctuations, and this needs further work to provide quantitative and higher-resolution results in the future.

\section{Conclusions}

Some defects have been identified in the previous palaeomagnetic chronological frameworks because of the lack of reliable control ages for the identification of palaeomagnetic chrons. Combined with the most recently published isotopic ages of volcanic ash and biostratigraphic dating, a new chronological framework has been proposed; the results show that the age of the Datang profile is between 72 and 62.8 Ma.

Many aquatic fossils, such as ostracods and charophytes, were found in the red strata, and the sediments were interpreted as fluvial or lacustrine facies; however, haematite is the dominant magnetic mineral throughout the profile, and palaeosol layers, pedogenic carbonates, wormhole remains, root traces, clear rhizoliths and mud cracks were found, which indicates that rivers or lakes, if present, appeared only temporarily in these hot and (semi-)arid environments such that the sediments were exposed to (semi-)arid and oxidising conditions for long periods of time and experienced different degrees of pedogenesis.

The variations in $\chi$ were controlled by the concentration of haematite, which was generated through LTO and chemical weathering during pedogenesis in a hot and (semi-)arid environment. Moreover, the stronger the pedogenic processes, the more haematite was generated and the higher the $\chi$ values.

The $\chi$ curve of the Datang profile is similar to the $\delta^{18} \mathrm{O}$ curves of corresponding marine sediments, which suggests that climate changes in the Nanxiong Basin during 7262.8 Ma were similar to global trends and can be divided into three stages: (1) a relatively hot and wet climate from 72 to $71.5 \mathrm{Ma}$ with a rapid drying and cooling event at $\sim 71.7 \mathrm{Ma}$; (2) a relatively cool and arid climate with secondary fluctuations from 71.5 to $66 \mathrm{Ma}$; and (3) a relatively hot and wet climate again from 66 to $62.8 \mathrm{Ma}$, which can be divided into three sub-stages. (i) The climate quickly became hot and wet from 66 to $64.7 \mathrm{Ma}$, (ii) a notable drying and cooling event occurred at $64.7-63.4 \mathrm{Ma}$, and (iii) there was a relatively hot and wet climate from 63.4 to $62.8 \mathrm{Ma}$.

Data availability. The data in this work are available upon request by contacting the corresponding author (xliu@fjnu.edu.cn).

Author contributions. MM and XL designed the experiments and WW carried them out. MM prepared the paper with contributions from all co-authors.

Competing interests. The authors declare that they have no conflict of interest.

Acknowledgements. The authors thank Xianqiu Zhang (China New Star (Guangzhou) Petroleum Corporation) for his generous help with fieldwork. This research was supported by the National Science Foundation of China (grant nos. 41210002, 41602185, and U1405231), the Natural Science Foundation of Fujian Province (grant no. 2016J05095), and Non-Profit Research Funds of Fujian Province (grant no. 2016R10323).

Edited by: Marit-Solveig Seidenkrantz

Reviewed by: two anonymous referees

\section{References}

Balsam, W. L. and Deaton, B. C.: Sediment dispersal in the Atlantic Ocean - evaluation by visible-light spectra, Rev. Aquat. Sci., 4, 411-447, 1991.

Balsam, W., Ji, J. F., and Chen, J.: Climatic interpretation of the Luochuan and Lingtai loess sections, China, based on changing iron oxide mineralogy and magnetic susceptibility, Earth Planet. Sc. Lett., 223, 335-348, 2004.

Barrera, E. and Savin, S. M.: Evolution of late CampanianMaastrichtian marine climates and oceans, in: Evolution of the Cretaceous Ocean-Climate System, edited by: Barrera, E. and Johnson, C., Geol. Soc. Am. Spec. Pap., 332, 245-282, 1999.

Bechtel, A., Jia, J., Strobl, S. A. I., Sachsenhofer, R. F., Liu, Z., Gratzer, R., and Püttmann, W.: Palaeoenvironmental conditions during deposition of the Upper Cretaceous oil shale sequences in the Songliao Basin (NE China): Implications from geochemical analysis, Org. Geochem., 46, 76-95, 2012.

Bodin, S., Meissner, P., Janssen, N. M. M., Steuber, T., and Mutterlose, J.: Large igneous provinces and organic carbon burial: Controls on global temperature and continental weathering during the Early Cretaceous, Global Planet. Change, 133, 238-253, 2015.

Buck, B. J., Hanson, A. D., Hengst, R. A., and Hu, S.: "Tertiary Dinosaurs" in the Nanxiong Basin, Southern China, Are Reworked from the Cretaceous, J. Geol., 112, 111-118, 2004. 
Chamberlain, C. P., Mix, H. T., Mulch, A., Hren, M. T., KentCorson, M. L., Davis, S. J., Horton, T. W., and Graham, S. A.: The Cenozoic climatic and topographic evolution of the western North American Cordillera, Am. J. Sci., 312, 213-262, 2012.

Chamberlain, C. P., Wan, X., Graham, S. A., Carroll, A. R., Doebbert, A. C., Sageman, B. B., Blisniuk, P., Kent-Corson, M. L., and Wang, Z.: Stable isotopic evidence for climate and basin evolution of the Late Cretaceous Songliao basin, China, Palaeogeogr. Palaeocl., 385, 106-124, 2013.

Chen, J., An, Z., Liu, L., Ji, J., Yang, J., and Chen, Y.: Variations in chemical compositions of the eolian dust in Chinese Loess Plateau over the past $2.5 \mathrm{Ma}$ and chemical weathering in the Asian inland, Sci. China Earth Sci., 44, 403-413, 2001.

Chen, J., Zhao, P., Wang, C., Huang, Y., and Cao, K.: Modeling East Asian climate and impacts of atmospheric $\mathrm{CO}_{2}$ concentration during the late Cretaceous (66 Ma), Palaeogeogr. Palaeocl., 385, 190-201, 2013.

Chen, T., Xu, H., Xie, Q., Chen, J., Ji, J., and Lu, H.: Characteristics and genesis of maghemite in Chinese loess and paleosols: mechanism for magnetic susceptibility enhancement in paleosols, Earth Planet. Sc. Lett., 240, 790-802, 2005.

Chumakov, N. M.: Climatic zones and climate of the Cretaceous period, in: Climate in the epochs of major biospheric transformations, edited by: Semikhatov, M. A. and Chumakov, N. M., Transactions of the Geological Institute of the Russian Academy of Sciences, 105-123, 2004.

Clyde, W. C., Ting, S., Snell, K. E., Bowen, G. J., Tong, Y., Koch, P. L., Li, Q., and Wang, Y.: New Paleomagnetic and StableIsotope Results from the Nanxiong Basin, China: Implications for the K/T Boundary and the Timing of Paleocene Mammalian Turnover, J. Geol., 118, 131-143, 2010.

Cogoini, M., Elmore, R. D., Soreghan, G. S., and Lewchuk, M. T.: Contrasting rock-magnetic characteristics of two Upper Paleozoic loessite-paleosol profiles, Phys. Chem. Earth Solid Earth Geod., 26, 905-910, 2001.

Cramer, B. S., Toggweiler, J. R., Wright, J. D., Katz, M. E., and Miller, K. G.: Ocean overturning since the late cretaceous: inferences from a new benthic foraminiferal isotope compilation, Paleoceanography, 24, 43-47, 2009.

Ding, Z. L., Xiong, S. F., Sun, J. M., Yang, S. L., Gu, Z. Y., and Liu, T. S.: Pedostratigraphy and paleomagnetism of a $\sim 7.0 \mathrm{Ma}$ eolian loess-red clay sequence at Lingtai, Loess Plateau, northcentral China and the implications for paleomonsoon evolution, Palaeogeogr. Palaeocl., 152, 49-66, 1999.

Ding, Z. L., Sun, J. M., Yang, S. L., and Liu, T. S.: Geochemistry of the pliocene red clay formation in the Chinese Loess Plateau and implications for its origin, source provenance and paleoclimate change, Geochim. Cosmochim. Ac., 65, 901-913, 2001.

Erben, H. K., Ashraf, A. R., Böhm, H., Hahn, G., Hambach, U., Krumsiek, K., Stets, J., Thein, J., and Wuster, P.: Die Kreide/Tertiär-Grenze im Nanxiong-Becken (Kontinentalfazies, Südostchina), Erdwissenschaftliche Forschung, 32, 1-245, 1995.

Evans, M. E. and Heller, F.: Magnetism of loess/palaeosol sequences: recent developments, Earth Sci. Rev., 54, 129-144, 2001.

Evans, M. E. and Heller, F.: Environmental magnetismprinciples and applications of environmagnetics, Acdemic Press, San Diego, CA, USA, 2003.
Fagel, N., Allan, M., Roux, G. L., Mattielli, N., Piotrowska, N., and Sikorski, J.: Deciphering human-climate interactions in an ombrotrophic peat record: REE, ND and $\mathrm{Pb}$ isotope signatures of dust supplies over the last 2500 years (Misten bog, Belgium), Geochim. Cosmochim. Ac., 135, 288-306, 2014.

Fang, X., Zan, J., Appel, E., Lu, Y., Song, C., and Dai, S.: An Eocene-Miocene continuous rock magnetic record from the sediments in the Xining Basin, NW China: indication for Cenozoic persistent drying driven by global cooling and Tibetan Plateau uplift, Geophys. J. Int., 201, 78-89, 2015.

Friedrich, O., Norris, R. D., and Erbacher, J.: Evolution of middle to Late Cretaceous oceans - A 55 m.y. record of Earth's temperature and carbon cycle, Geology, 40, 107-110, 2012.

Fu, C., Bloemendal, J., Qiang, X., Hill, M. J., and An, Z.: Occurrence of greigite in the Pliocene sediments of Lake Qinghai, China, and its paleoenvironmental and paleomagnetic implications, Geochem. Geophy. Geosy., 16, 1293-1306, 2015.

Gao, Y., Ibarra, D. E., Caves, J. K., Wang, C., Caves, J. K., Chamberlain, C. P., Graham, S. A., and Wu, H.: Mid-latitude terrestrial climate of East Asia linked to global climate in the Late Cretaceous, Geology, 43, 287-290, 2015.

Gradstein, F. M., Ogg, J. G., Schmitz, M. D., and Ogg, G. M.: The geologic time scale, Elsevier, Amsterdam, the Netherlands, 2012.

Han, J., Keppens, E., Liu, T., Paepe, R., and Jiang, W.: Stable isotope composition of the carbonate concretion in loess and climate change, Quatern. Int., 37, 37-43, 1997.

Hao, Q. and Guo, Z.: Spatial variations of magnetic susceptibility of Chinese loess for the last $600 \mathrm{kyr}$ : implications for monsoon evolution, J. Geophys. Res.-Solid Earth, 110, B12101, https://doi.org/10.1029/2005JB003765, 2005.

Hao, Q. Z., Oldfield, F., Bloemendal, J., and Guo, Z. T.: A preliminary study of the magnetic properties of loess and palaeosol samples from the Chinese Loess Plateau spanning the last 22 million years, Palaeogeogr. Palaeocl., 260, 389-404, 2008.

Hasegawa, H., Tada, R., Jiang, X., Suganuma, Y., Imsamut, S., Charusiri, P., Ichinnorov, N., and Khand, Y.: Drastic shrinking of the Hadley circulation during the mid-Cretaceous Supergreenhouse, Clim. Past, 8, 1323-1337, https://doi.org/10.5194/cp-81323-2012, 2012.

Hay, W. W.: Can humans force a return to a 'Cretaceous' climate?, Sediment. Geol., 235, 5-26, 2011.

Hu, S., Goddu, S. R., Herb, C., Appel, E., Lleixner, G., Wang, S., Yang, X., and Zhu, X.: Climate variability and its magnetic response recorded in a lacustrine sequence in Heqing basin at the SE Tibetan Plateau since 900 ka, Geophys. J. Int., 201, 444-458, 2015.

Huang, C. M., Retallack, G. J., and Wang, C. S.: Early Cretaceous atmospheric $p \mathrm{CO}_{2}$ levels recorded from pedogenic carbonates, Cretaceous Res., 33, 42-49, 2012.

Huang, C., Retallack, G. J., Wang, C., and Huang, Q.: Paleoatmospheric $\mathrm{pCO}_{2}$, fluctuations across the Cretaceous-Tertiary boundary recorded from paleosol carbonates in NE china, Palaeogeogr. Palaeocl., 385, 95-105, 2013.

Huber, B. T., Hodell, D. A., and Hamilton, C. P.: Mid- to Late Cretaceous climate of the southern high latitudes: stable isotopic evidence for minimal equator-to-pole thermal gradients, Geol. Soc. Am. Bull., 107, 392-417, 1995. 
Huber, B. T., Norris, R. D., and Macleod, K. G.: Deep-sea paleotemperature record of extreme warmth during the Cretaceous, Geology, 30, 123-126, 2002.

Ji, J. F., Balsam, W., and Chen, J.: Mineralogic and climatic interpretations of the Luochuan loess section (China) based on diffuse reflectance spectrophotometry, Quat. Res., 56, 23-30, 2001.

Ji, J., Zhao, L., Balsam, W., Chen, J., Wu, T., and Liu, L.: Detecting chlorite in the Chinese loess sequence by diffuse reflectance spectroscopy, Clay. Clay Miner., 54, 266-273, 2006.

Jiang, X., Pan, Z., Xu, J., Li, X., Xie, G., and Xiao, Z.: Late Cretaceous aeolian dunes and reconstruction of palaeo-wind belts of the Xinjiang Basin, Jiangxi province, China, Palaeogeogr. Palaeocl., 257, 58-66, 2008.

Jiang, Z., Liu, Q., Barrón, V., Torrent, J., and Yu, Y.: Magnetic discrimination between Al-substituted hematites synthesized by hydrothermal and thermal dehydration methods and its geological significance, J. Geophys. Res.-Solid Earth, 117, 119-130, 2012.

Jiang, Z., Liu, Q., Zhao, X., Jin, C., Liu, C., and Li, S.: Thermal magnetic behaviour of Al-substituted haematite mixed with clay minerals and its geological significance, Geophys. J. Int., 200, 130-143, 2015.

Kraus, M. J. and Hasiotis, S. T.: Significance of different modes of rhizolith preservation to interpreting paleoenvironmental and paleohydrologic settings: examples from paleogene paleosols, Bighorn Basin, Wyoming, USA, J. Sediment. Res., 76, 633-646, 2006.

Larrasoaña, J. C., Roberts, A. P., and Rohling, E. J.: Magnetic susceptibility of eastern Mediterranean marine sediments as a proxy for Saharan dust supply?, Mar. Geol., 254, 224-229, 2008.

Levy, D., Giustetto, R., and Hoser, A.: Structure of magnetite $\left(\mathrm{Fe}_{3} \mathrm{O}_{4}\right)$ above the Curie temperature: a cation ordering study, Phys. Chem. Miner., 39, 169-176, 2012.

Li, G., Hirano, H., Batten, D. J., and Wan, X.: Biostratigraphic significance of spinicaudatans from the Upper Cretaceous Nanxiong Group in Guangdong, South China, Cretaceous Res., 31, 387395, 2010.

Li, J., Wen, X. Y., and Huang, C. M.: Lower Cretaceous paleosols and paleoclimate in Sichuan Basin, China, Cretaceous Res., 62, 154-171, 2015.

Li, M.: Sporo-pollen from Shanghu Formation of Early Paleocene in Nanxiong Basin, Guangdong, Acta Palaeontologica Sinica, 28, 741-750, 1989 (in Chinese with English abstract).

Li, X., Xu, W., Liu, W., Zhou, Y., Wang, Y., Sun, Y., and Liu, L.: Climatic and environmental indications of carbon and oxygen isotopes from the Lower Cretaceous calcrete and lacustrine carbonates in Southeast and Northwest China, Palaeogeogr. Palaeocl., 385, 171-189, 2013.

Li, Y. W.: The Application of Ostracoda to the Location of the Non-marine Jurassic-Cretaceous Boundary in the Sichuan Basin of China, Developments Palaeontology Stratigraphy, 11, 12451260, 1988.

Linnert, C., Robinson, S. A., Lees, J. A., Bown, P. R., PérezRodriguez, I., Petrizzo, M. R., Falzoni, F., Littler, K., Arz, J. A., and Russell, E. E.: Evidence for global cooling in the Late Cretaceous, Nat. Commun., 5, 1-7, 2014.

Liu, Q. S., Deng, C. L., Yu, Y. J., Torrent, J., Jackson, M. J., Banerjee, S. K., and Zhu, R.: Temperature dependence of magnetic susceptibility in an argon environment: implications for pedogene- sis of Chinese loess/palaeosols, Geophys. J. Int., 161, 102-112, 2005.

Liu, T. S.: Loess and Environment, Science Press, Beijing, 1-481, 1985 (in Chinese).

Liu, X., Shaw, J., Liu, T., Heller, F., and Yuan, B.: Magnetic mineralogy of Chinese loess and its significance, Geophys. J. Int., 108, 301-308, 1992.

Liu, X. M., Hesse, P., and Rolph, T.: Origin of maghaemite in Chinese loess deposits: Aeolian or pedogenic?, Phys. Earth Planet Inter., 112, 191-201, 1999.

Liu, X. M., Rolph, T., An, Z., and Hesse, P.: Paleoclimatic significance of magnetic properties on the Red Clay underlying the loess and paleosols in China, Palaeogeogr. Palaeocl., 199, 153166, 2003.

Lu, H. M. and Meng, X. K.: Morin Temperature and Néel Temperature of Hematite Nanocrystals, J. Phys. Chem. C., 114, 2129121295, 2010.

Ma, M., Liu, X., Pillans, Brad J., Hu, S., Lü, B., and Liu, H.: Magnetic properties of Dashing Rocks loess at Timaru, South Island, New Zealand, Geophys. J. Int., 195, 75-85, 2013.

Maher, B. A.: Palaeoclimatic records of the loess/palaeosol sequences of the Chinese Loess Plateau, Quat. Sci. Rev., 154, $23-$ 84, 2016.

Maher, B. A. and Possolo, A.: Statistical models for use of palaeosol magnetic properties as proxies of palaeorainfall, Global Planet. Change, 111, 280-287, 2013.

Maher, B. A., Thompson, R., and Zhou, L. P.: Spatial and temporal reconstructions of changes in the Asian palaeomonsoon - a new mineral magnetic approach, Earth Planet. Sc. Lett., 125, 461471, 1994.

Nie, J., King, J. W., and Fang, X.: Enhancement mechanisms of magnetic susceptibility in the Chinese red-clay sequence, Geophys. Res. Lett., 341, 255-268, 2007.

Nie, J., King, J. W., and Fang, X.: Link between benthic oxygen isotopes and magnetic susceptibility in the red-clay sequence on the Chinese Loess Plateau, Geophys. Res. Lett., 35, 154-175, 2008.

Nie, J., Zhang, R., Necula, C., Heslop, D., Liu, Q., Gong, L., and Banerjee, S.: Late Miocene-early Pleistocene paleoclimate history of the Chinese Loess Plateau revealed by remanence unmixing, Geophys. Res. Lett., 41, 2163-2168, 2014.

Nie, J., Song, Y., and King, J.: A review of recent advances in red-clay environmental magnetism and paleoclimate history on the Chinese Loess Plateau, Front. Earth Sci., 4, 27, https://doi.org/10.3389/feart.2016.00027, 2016.

Peters, C., Austin, W. E. N., Walden, J., and Hibbert, F. D.: Magnetic characterisation and correlation of a Younger Dryas tephra in North Atlantic marine sediments, J. Quaternary Sci., 25, 339347, 2010.

Rankey, E. C. and Farr, M. R.: Preserved pedogenic mineral magnetic signature, pedogenesis, and paleoclimate change. Pennsylvanian Roca Shale (Virgilian, Asselian), central Kansas, USA, Sediment. Geol., 114, 11-32, 1997.

Renne, P. R., Deino, A. L., Hilgen, F. J., Kuiper, K. F., Mark, D. F., Mitchell, W. S., Morgan, L. E., Mundil, R., and Smit, J.: Time Scales of Critical Events Around the Cretaceous-Paleogene Boundary, Science, 339, 684-687, 2013. 
Retallack, G. J.: Untangling the effects of burial alteration and ancient soil formation, Annu. Rev. Earth Planet. Sc., 19, 183-206, 1991.

Retallack, G. J.: Depth to pedogenic carbonate horizon as a paleoprecipitation indicator?: Comment and Reply, Geology, 27, 41$52,1999$.

Retallack, G. J.: Pedogenic carbonate proxies for amount and seasonality of precipitation in paleosols, Geology, 33, 333-336, 2005.

Retallack, G. J.: Greenhouse crises of the past 300 million years, Geol. Soc. Am. Bull., 121, 1441-1455, 2009.

Retallack, G. J., Sheldon, N. D., Cogoini, M., and Elmore, R. D.: Magnetic susceptibility of early Paleozoic and Precambrian paleosols, Palaeogeogr. Palaeocl., 198, 373-380, 2003.

Russell, D. A., Russell, D. E., and Sweet, A. R.: The end of the dinosaurian era in the Nanxiong Basin, Certebrata Palasiatica, 31, 139-145, 1993.

Schulte, P., Alegret, L., Arenillas, I., Arz, J. A., Barton, P. J., Bown, P. R., Bralower, T. J., Christeson, G. L., Claeys, P., Cockell, C. S., Collins, G. S., Deutsch, A., Goldin, T. J., Goto, K., GrajalesNishimura, J. M., Grieve, R. A. F., Gulick, S. P. S., Johnson, K. R., Kiessling, W., Koeberl, C., Kring, D. A., Macleod, K. G., Matsui, T., Melosh, J., Montanari, A., Morgan, J. V., Neal, C. R., Norris, R. D., Pierazzo, E., Ravizza, G., Rebolledo-Vieyra, M., Reimold, W. U., Robin, E., Salge, T., Speijer, R. P., Sweet, A. R., Urrutia-Fucugauchi, J., Vajda, V., Whalen, M. T., and Willumsen, P. S.: Response - Cretaceous Extinctions, Science, 328, 975-976, 2010.

Schwartzmann, D. W. and Volk, T.: Biotic enhancement of weathering and surface temperatures of Earth since the origin of life, Palaeogeogr. Palaeocl., 90, 357-371, 1991.

Scotese, C. R.: KT Globe, (KT_Pgeog_357.kmz, Google Earth format), available at: www.globalgeology.com, PALEOMAP Project, Evanston, IL.KT_Pgeog_357, 2014.

Shu, L., Deng, P., Wang, B., Tan, Z., Yu, X., and Sun, Y.: Lithology, kinematics and geochronology related to Late Mesozoic basin-mountain evolution in the Nanxiong-Zhuguang area, South China, Sci. China Earth Sci., 47, 673-688, 2004.

Shunso, I., Hua, R., Mihoko, H., and Hiroyasu, M.: REE Abundance and REE Minerals in Granitic Rocks in the Nanling Range, Jiangxi Province, Southern China, and Generation of the REErich Weathered Crust Deposits, Resour. Geol., 58, 355-372, 2010.

Sidhu, P. S.: Transformation of trace element-substituted maghemite to hematite, Clay. Miner., 36, 31-38, 1988.

Smith, D. O.: Magnetization of a Magnetite Single Crystal Near the Curie Point, Phys. Rev., 102, 959-963, 1956.

Snowball, I., Sandgren, P., and Petterson, G.: The mineral magnetic properties of an annually laminated Holocene lake-sediment sequence in northern Sweden, Holocene, 9, 353-362, 1999.

Thompson, R. and Oldfield, F.: Environmental Magnetism, Allen \& Unwin, London, 1-228, 1986.

Tong, Y., Li, Q., and Wang, Y. Q.: An Introduction to recent advance in the study of the continental Early Paleogene stages in China, J. Stratigraphy, 37, 428-440, 2013 (in Chinese with English abstract).

Torrent, J., Barrón, V., and Liu, Q. S.: Magnetic enhancement is linked to and precedes hematite forma- tion in aerobic soils, Geophys. Res. Lett., 33, L02402, https://doi.org/10.1029/2005GL024818, 2006.

Torrent, J., Liu, Q. S., Bloemendal, J., and Barrón, V.: Magnetic enhancement and iron oxides in the upper luochuan loess-paleosol sequence, Chinese Loess Plateau, Soil Sci. Soc. Am. J., 71, 1570-1578, 2007.

Tramp, K. L., Soreghan, G. S., and Elmore, R. D.: Paleoclimatic inferences from paleopedology and magnetism of the Permian Maroon Formation loessite, Colorado, USA, Geol. Soc. Am. Bull., 116, 671-686, 2004.

Van Velzen, A. J. and Dekkers, M. J.: Low-temperature oxidation of magnetite in loess-paleosol sequences: a correction of rock magnetic parameters, Stud. Geophys. Geod., 43, 357-375, 1999.

Wan, X., Zhao, J., Scott, R. W., Wang, P., Feng, Z., Huang, Q., and Xi, D.: Late Cretaceous stratigraphy, Songliao Basin, NE China: SK1 cores, Palaeogeogr. Palaeocl., 385, 31-43, 2013.

Wang, C., Feng, Z., Zhang, L., Huang, Y., Cao, K., Wang, P., and Zhao, B.: Cretaceous paleogeography and paleoclimate and the setting of SKI borehole sites in Songliao Basin, northeast China, Palaeogeogr. Palaeocl., 385, 17-30, 2013a.

Wang, C., Scott, R. W., Wan, X., Graham, S. A., Huang, Y., Wang, P., Wu, H., Dean, W. E., and Zhang, L.: Late Cretaceous climate changes recorded in Eastern Asian lacustrine deposits and North American Epieric sea strata, Earth-Sci. Rev., 126, 275299, 2013 b.

Wang, Y.: Paleoclimate changes of thr Late Cretaceous-Late Paleocene in the Nanxiong Basin, South China, Nanjing University, 2012 (in Chinese with English abstract).

Wang, Y., Huang, C., Sun, B., Quan, C., Wu, J., and Lin, Z.: Paleo$\mathrm{CO}_{2}$ variation trends and the Cretaceous greenhouse climate, Earth-Sci. Rev., 129, 136-147, 2014.

Wang, Y., Li, X., Zhou, Y., and Liu, L.: Paleoclimate indication of Terrigenous clastic rock's component during the Late Cretaceous-Early Paleocene in the Nanxiong Basin, Acta Sedimentologica Sinica, 33, 116-123, 2015 (In Chinese with English abstract).

Wilson, P. A., Norris, R. D., and Cooper, M. J.: Testing the Cretaceous greenhouse hypothesis using glassy foraminiferal calcite from the core of the Turonian tropics on Demerara Rise, Geology, 30, 607-610, 2002.

Wu, H., Zhang, S., Jiang, G., and Huang, Q.: The floating astronomical time scale for the terrestrial Late Cretaceous Qingshankou Formation from the Songliao Basin of Northeast China and its stratigraphic and paleoclimate implications, Earth Planet Sc. Lett., 278, 308-323, 2009.

Xie, Q.: Nanominerals of the loess-red clay sequences in Chinese Loess Plateau, Hefei University of Technology, 2008 (in Chinese with English abstract).

Xiong, S., Ding, Z., Zhu, Y., Zhou, R., and Lu, H.: A 6 Ma chemical weathering history, the grain size dependence of chemical weathering intensity, and its implications for provenance change of the Chinese loess-red clay deposit, Quaternary Sci. Rev., 29, 1911-1922, 2010.

Yan, Y., Xia, B., Lin, G., Cui, X., Hu, X., Yan, P., and Zhang, F.: Geochemistry of the sedimentary rocks from the Nanxiong Basin, South China and implications for provenance, paleoenvironment and paleoclimate at the K/T boundary, Sediment. Geol. 197, 127-140, 2007. 
Yang, W., Chen, N., Ni, S., Nan, J., Wu, M., Jiang, J., Ye, J., Feng, X., and Ran, Y.: Carbon and Oxygen Isotopic Compositions of the Carbonate Rocks and the Dinosaur Eggshells in the Cretaceous Red Beds and Their Implication for Paleoenvironment, Chinese Sci. Bull., 38, 1985-1989, 1993.

Ye, J.: Discussion on the problems of the K/T Boundary in the Nanxiong Basin, Certebrata Palasiatica, 38, 1-9, 2000.

Zachos, J., Pagani, M., Sloan, L., Thomas, E., and Billups, K.: Trends, Rhythms, and Aberrations in Global Climate 65 Ma to Present, Science, 292, 686-693, 2001.

Zhang, L.: Paleoclimatic evolution and mechanism of the mass extinction during the K-Pg boundary: Evidences from several terrestrial basins in East China, China University of Geosciences (Beijing), 2016 (in Chinese with English abstract).

Zhang, Q.: Paleocene sporopollen assemblages in the Nanxiong Basin Guangdong Province, in: Bull. Yichang Inst. Geol. M. R., Chinese Acad. Geol. Sci. Sp. Iss. S. P., 106-117, 1981 (in Chinese with English abstract).

Zhan, T., Guo, Z. T., Wu, H. B., Ge, J., Zhou, X., Wu, C., and Zeng, F.: Thick Miocene eolian deposits on the Huajialing Mountains: The geomorphic evolution of the western Loess Plateau, Sci. China Earth Sci., 54, 241-248, 2011.

Zhang, W., Erwin, A., Fang, X., Yan, M., Song, C., and Cao, L.: Paleoclimatic implications of magnetic susceptibility in Late Pliocene-Quaternary sediments from deep drilling core SG-1 in the western Qaidam Basin (NE Tibetan Plateau), J. Geophys. Res., 117, 6101, https://doi.org/10.1029/2011JB008949, 2012.

Zhang, X.: A study on Ostracod fauna of Shanghu Formation and Cretaceous-Tertiary Boundary in Nanxiong Basin, Guangdong, Acta Micropalaeontologica Sinica, 6, 678-702, 1992 (in Chinese with English abstract).

Zhang, X. and Li, G.: Discussion on geological age of the Pingling Member of Shanghu Formation in the Nanxiong Basin,Guangdong Province, J. Stratigraphy, 39, 74-80, 2015 (in Chinese with English abstract).
Zhang, X. and Li, S.: New progress in stratigraphic study of the western area of Nanxiong Basin, Guangdong Geology, 15, 9-18, 2000 (in Chinese with English abstract).

Zhang, X., Lin, J., Li, G., and Lin, Q.: Non-marine CretaceousPaleogene boundary section at Datang, Nanxiong, northern Guangdong, J. Stratigraphy, 30, 327-340, 2006 (in Chinese with English abstract).

Zhang, X., Zhang, X., Hou, M., Li, G., and Li, H.: Lithostratigraphic subdivision of red beds in Nanxiong Basin, Guangdong, China, J. Stratigraphy, 37, 441-451, 2013 (in Chinese with English abstract).

Zhao, G., Han, Y., Liu, X., Chang, L., Lü, B., Chen, Q., Guo, X., Yan, J., and Yan, J.: Can the magnetic susceptibility record of Chinese Red Clay sequence be used for palaeomonsoon reconstructions?, Geophys. J. Int., 204, 1421-1429, 2016.

Zhao, Z. and Yan, Z.: Stable isotopic studies of dinosaur eggshells from the Nanxiong Basin, South China, Sci. China Earth Sci., 43, 84-92, 2000.

Zhao, Z., Mao, X., Chai, Z., Yang, G., Zhang, F., and Yan, Z.: Geochemical environmental changes and dinosaur extinction during the Cretaceous-Paleogene $(\mathrm{K} / \mathrm{T})$ transition in the Nanxiong Basin, South China: Evidence from dinosaur eggshells, Chinese Sci. Bull., 54, 806-815, 2009.

Zhao, Z. K., Ye, J., and Li, H. M.: Extinction of the dinosaurs across the Cretaceous-Tertiary boundary in Nanxiong Basin, Guangdong Province, Certebrata Palasiatica, 29, 1-20, 1991 (in Chinese with English abstract).

Zhao, Z. K., Mao, X. Y., Chai, Z. F., Yang, G., Kong, P., Ebihara, M., and Zhao, Z.: A possible causal relationship between extinction of dinosaurs and $\mathrm{K} / \mathrm{T}$ iridium enrichment in the Nanxiong Basin, South China: evidence from dinosaur eggshells, Palaeogeogr. Palaeocl., 178, 1-17, 2002.

Zhou, L. P., Oldfield, F., Wintle, A. G., Robinson, S. G., and Wang, J.: Partly pedogenic origin of magnetic variations in Chinese loess, Nature, 346, 737-739, 1990. 